\title{
Fashioning the Academic and Private Self: The Clothing of Johanna Westerdijk in the Context of her Biography
}

By Marta Kargól

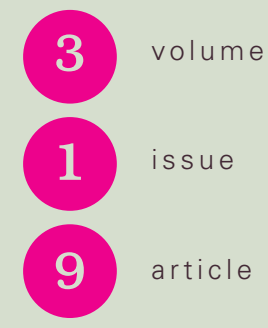

KEYWORDS:

JOHANNA WESTERDIJK ACADEMIC CAREER FEMALE DRESS APPROACH TO FASHION BIOGRAPHY IDENTITY PERSONAL STYLE
This article aims to analyze the clothing of Dutch botanist Johanna Westerdijk (1883-1961) in connection with her biography, academic career, and character. A thorough analysis of changes and constants in her clothing reveals her personal style and approach to fashion, made possible due to the significant number of Westerdijk's portraits - the primary source for this study. Her sartorial sense, as seen in these photographs, mirrors the manner in which Westerdijk defined herself, both as a woman and scholar. The variety of Westerdijk's portraits allow us to analyze her clothing during official ceremonies, at work, in daily life situations, her travel outfits as well as her dressing-up and cross-dressing practices. This article indicates that these visual sources provide interesting insights into how Westerdijk fashioned herself. The purpose of the article is to investigate the extent to which research into biography and dress history can be mutually illuminating. 


\section{INTRODUCTION}

On January 1st, 1917, 34-year-old Johanna Westerdijk was the first woman in the Netherlands to be awarded the title of professor at the University of Utrecht. On the January 20th of the same year, a photograph of Westerdijk in her workplace was published in the magazine Eigen Haard (Figure 1). The photo shows Westerdijk in a white blouse with pleats and slightly puffy sleeves. Her smoothly combed hair is pinned to the back of her head, with light, round eyeglasses resting on the bridge of her nose. Another photo in De Indische Mercuur (Figure 2) was published in the same year, showing Westerdijk seated behind her desk, flanked by test tubes and research instruments. Her elegant blouse has a standing frilly collar, similar to the ends of the sleeves that adorned her wrists. Both pictures are certainly meant to depict the image of an intellectual and educated woman. Simultaneously, they trigger several questions: what is the relevance of clothing in these images? What was the significance of appearance and clothing in the private and professional lives of Johanna Westerdijk? Does clothing play a major role in negotiating the position of a female academic professional in the social space of the university? What does the clothing reveal about the relationship between the private and professional lives of Westerdijk?

\section{To what extent can} biographical data be used to define the sartorial sense of a historical individual? How can the analysis of someone's personal style extend the biographical knowledge of an individual?

Thus, this article aims to analyze Westerdijk sartorially in connection with her biography, academic career, and character. A thorough analysis of changes and constants in her clothing reveals her personal style and approach to fashion. The clothing, as seen in photographs, mirrors how Westerdijk defined herself, both as a woman and a scholar. 


\section{Professor Dr. dohanna Westerdijk.}

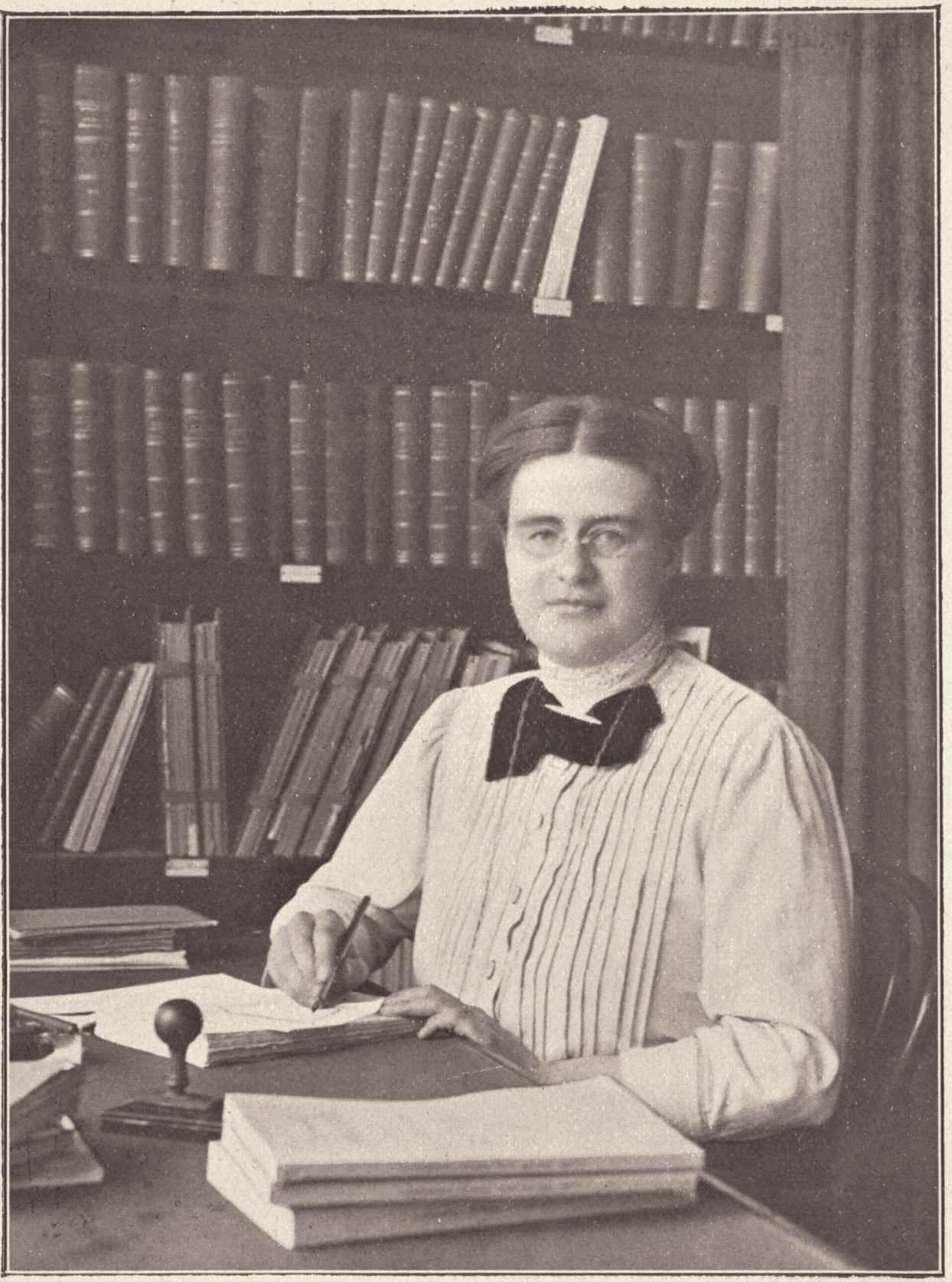

5720

studie de grondslagen hier gelegd. Prof. F. A. F. C. Went voor de aar zij 't grootste deel van haar nistes gesticht met een kleine hos feneration der Lebermoose - onder welke thans tot een duizendtal zi

FIGURE 1 Johanna Westerdijk behind her desk, 1917. Collection: Atria. The Institute on Gender Equality and Women's History in Amsterdam. Kennisinstituut voor Emancipatie en Vrouwengeschiedenis in Amsterdam (100005720). 


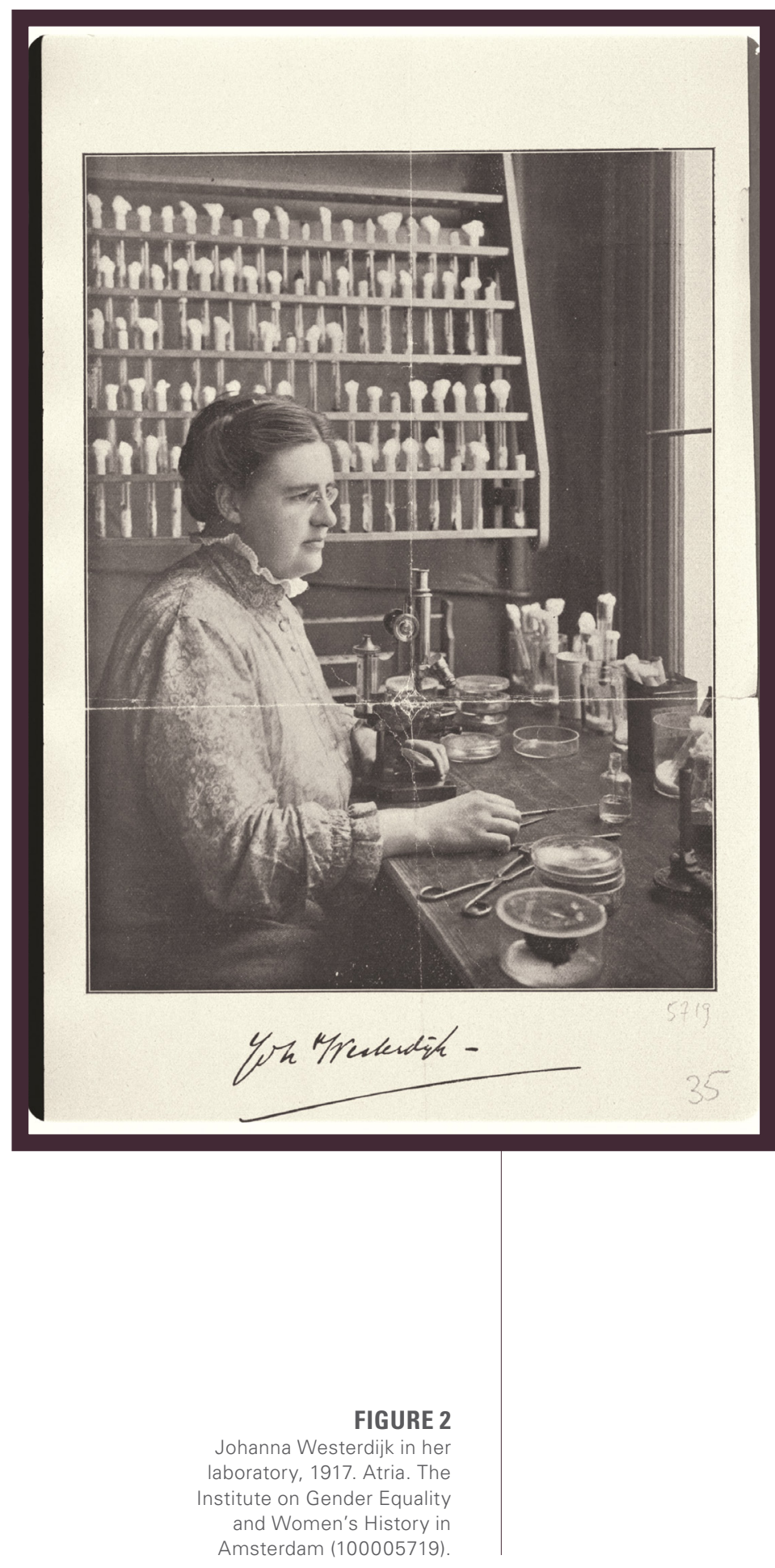




\section{THE PORTRAITS OF JOHANNA WESTERDIJK}

More than five hundred images of Johanna Westerdijk exist, including group portraits, landscapes, and images of interiors. Most photographs of Westerdijk are stored in the "Atria: Institute on Gender Equality and Women's History" archive in Amsterdam. The selection of photographs found in this study provide the farthest-reaching possible illustration of different moments in Westerdijk's life as well as a variety of daily situations and activities. Moreover, this selection is made up primary of the photographs that bear additional information on the time and the specific circumstances in which they were taken.

These photographs were taken between 1900 and 1959; however, the Atria collection does not include any of her portraits between 1920 and 1930. Photographs of Westerdijk are either located as individual objects in the collection, or part of the professor's private photo albums, making them particularly useful for the interpretation Westerdijk's dress. Some pictures in these albums are also accompanied by captions that provide contextual information, and many of the photos are dated, making the need for any estimations regarding her age or otherwise, unnecessary. The collection includes photos from various ceremonies and events such as academic promotions, travels, and field research. These last two categories are important because they help identify unusual situations requiring specific clothing, making it beneficial for reading the attitude of the researcher in relation to her own sartorial sense. 
Westerdijk's photos at work merit examination. Many portraits depict the Dutch scholar at her desk, in which the professor is seen reading, writing, or researching. The assumption is that third parties had an impact on the image creation; thus, caution is necessary in the interpretation of these pictures and the clothing worn. More than reflecting the scholar's personality, these pictures depict the typical image of a (female) professor. Undoubtedly, these images are unusual for the manner in which Westerdijk was included as a female scholar into a public space. That is, most of her portraits published in the press were often taken at her desk or in laboratory, highlighting the necessity to focus on female academics' professional positions in order to negate stereotypes and biases (Carli et al., 2016, pp. 244-260).

The method of analyzing the photos is accomplished through repeated observations that prompt new questions and answers. Another useful approach involves comparing photographs, analyzing them in different arrangements and paying attention to the smallest details, exceptions, and repetitions.

\section{The interpretation of clothing in the context of a photo includes the nature of the picture, the circumstances of its creation, the surroundings displayed, and even the overall aesthetics of the image. Finally, the touch of biographical knowledge from written sources should always be included in the interpretation of iconographic sources.}


BIOGRAPHICAL AND HISTORICAL FACTS

Johanna Westerdijk was born in Nieuwer-Amstel, North Holland, the Netherlands, on January 4th, 1883, into a well-established family of physicians (Faasse, 2012, p. 13). Her parents shared with her their passion for art, music (she was a talented pianist), and of course nature (Faasse, 2012, p. 15-28). She studied in Amsterdam and Munich and received her $\mathrm{PhD}$ from the University of Zürich (Faasse, 2012). Westerdijk became a prominent botanist, specializing in the cultures of fungi, and in 1917, she was appointed the first female professor in the Netherlands at the Utrecht University (Faasse, 2012, p. 149). In 1930, Westerdijk also received the title of professor from the University of Amsterdam (Zadoks \& Van Bruggen, 2008, p. 158). She travelled extensively to the Dutch East Indies, Japan, the United States, Portugal, and South Africa to conduct research (Zadoks \& Van Bruggen, 2008, p. 161, Faasse, 2012, p. 127).

At the age of twenty-three, Westerdijk was appointed the director of Willie Commelin Scholten, a phytopathological laboratory in the Netherlands. She remained in this position for most of her life, until 1952. Initially, Westerdijk ran her laboratory in Amsterdam but moved the facility in 1921 to Baarn, a village near Utrecht, in a villa called Java (Schippers \& Roosje, 1997, pp. 667-668). She developed the place into an academic colony where her students and subordinates worked and enjoyed leisure time together; it was also where she resided (Kerling et al., 1986, p. 39, Zadoks \& Van Bruggen, 2008, p. 165). Westerdijk was a demanding mentor but did not underestimate the importance of celebration and creative entertainment. Together with her students, she made music and performed plays (Faasse, 2012, p. 140). The villa also served as an asylum where she could distance herself from the male dominated academic environment and perform her job without being constantly forced into confrontation with her womanhood (Bosch, 1994, pp. 426-428).

Both male and female students were welcome in Westerdijk's laboratory, but she had an admittedly special bond with her female students, whom she exceptionally supported on their professional path (Pegtel, 2018, p. 109). Although she enjoyed their personal happiness, she regretted it when marriages ended their carrier (Faasse, 2012, p. 331; Pegtel, 2018, p. 109). The fact that during the period many women could not combine family life with a professional job explains her desire to never get married and her decision to focus on her academic career. Under Dutch law, married women were not allowed to participate in the labour market. This situation lasted until 1957 (Kloek, pp. 194-201). Westerdijk was neither politically engaged nor a declared feminist, but she openly fought against social restrictions on women and was devoted to female higher education. Because of this attitude, Westerdijk was described as an academic feminist (Bosch, 1994, pp. 408-412).

When she was a teenager, she started calling herself Hans - a popular Dutch male name - expressing her alter ego and association with her cross-dressing practices (Faasse, 2012, p. 20). Westerdijk dressed as a man only in her youth, and she did it sporadically, especially during her journeys when her womanhood felt like a limitation (Bosch, 
1994, pp. 420-421; Faasse, 2012, p. 68). At the end of her career, she claimed that being a woman had never been an obstacle in her academic progress (Bosch, 1988, p. 174), which was more of a reflection of her own attitude rather than the reality. The position of the Willie Commelin Scholten director was given to her as the institution was in a rather poor state, and none of respected male scientists would accept the offer (Zadoks \& Van Bruggen, 2008, p. 157; Faasse, 2012, pp. 83-92). Westerdijk used this opportunity to develop her career and contribute to the development of the institution (Kerling et al., 1986, p. 38; Bosch, 1994, pp. 399-104; Schippers, B., \& Roosje, 1997, pp. 667-668, Boonekamp et al., 2019). Contemporary female scientists, as well as female scientists today, face biases due to their gender in the context of their professional careers (LaFollette, 1988, pp. 262-275). Female scientists were often considered unusual, an attitude extended to Westerdijk as the first female professor in the Netherlands. Despite this, Westerdijk's personal view of her position in the academic environment seems to be more relevant for understanding her sartorial choices than the gendered social biases held against her status as a female academic (Zadoks \& Van Bruggen, 2008, p. 158).

\section{SPACE, PLACE, AND CIRCUMSTANCES}

The first aspect regarding the role of clothing in the context of biography is the space in which it is worn. Space can be distinguished into two types - private and public. Public space can be additionally divided into every day, and unusual. A university office and laboratory constituted Westerdijk's daily public spaces, while trav- elling can be considered an unusual space. This changing everyday environment could create the need to adapt clothing to specific circumstances. Moreover, the change of the cultural environment in the case of more distant travels has a significant influence on modifying one's clothing habits. These spaces can be assigned to various categories of activities such as academic celebrations, office work and fieldwork, and leisure time and travels.

\section{ACADEMIC CELEBRATIONS}

Official academic ceremonies were honoured by the obligatory attire assigned to them: an academic gown. The academic gown was, and is, an indicator of social function and position within the university. When Westerdijk became a professor at the University of Utrecht in 1917, two official photos of her in an academic gown were taken, where the gown functions as a uniform informing the newly awarded university degree. One image portrays the individual portrait of the researcher, where she stands proudly with a book in hand. The second photograph is a collective portrait of the academic staff of the University of Utrecht, and Westerdijk is seated almost in the centre of the first row, surrounded by men (Figure 3 ). Some of those photographed also wore their academic gowns, while others wore traditional men's suits. Under her academic gown Westerdijk wears a long monochrome dress with sleeves ending in a slight frill. The femininity of the dress does not diminish the seriousness of Westerdijk as an academic, but it does distinguish her from her male colleagues. This image reflects how she saw her position in the academic world, as she claimed that being a woman was not an obstacle to her 
professional success (Bosch, 1988, p. 174), and she did not feel threatened among other male academics - she therefore had no reason to mask her femininity.

Another photograph taken for this occasion is an informal one (Figure 4). Here, Westerdijk also wears her academic gown, but she is surrounded by friends or students in theatre costumes. This photo was taken during a private feast honouring Westerdijk for receiving a professorship in 1917. The students wrote a play in which they described her life and career path. They wrote about her years as a student in Munich and Zurich, where she would celebrate at carnivals and have drinks with her friends (Faasse, 2012, p. 150). Furthermore, they wrote about Westerdijk's travels to India and her stay in Japan (Faasse, 2012, p. 156). The costumes in the photograph can be linked to the specific events recorded in the play - two women are in imitational costumes of Bavarian traditional dress with large glasses of beer, recalling leisurely moments that Westerdijk enjoyed as a student. Other students are wearing free-flowing Indian dresses, and the figure with a whitened face in front of the photo is dressed as a geisha. This cultural appropriation would at the time have been considered unharmful, especially because of the private space in which it occurred, despite the racist actions perpetrated by Westerdijk's students and overlooked by Westerdijk herself during this performance. Seated among them, Westerdijk wears her academic gown and is poised casually and comfortably. Transferring the academic gown to private life and making it an element of informal entertainment resulted in the gown losing its dignity and seriousness. The outfit became - next to the costumes worn by others - a disguise.

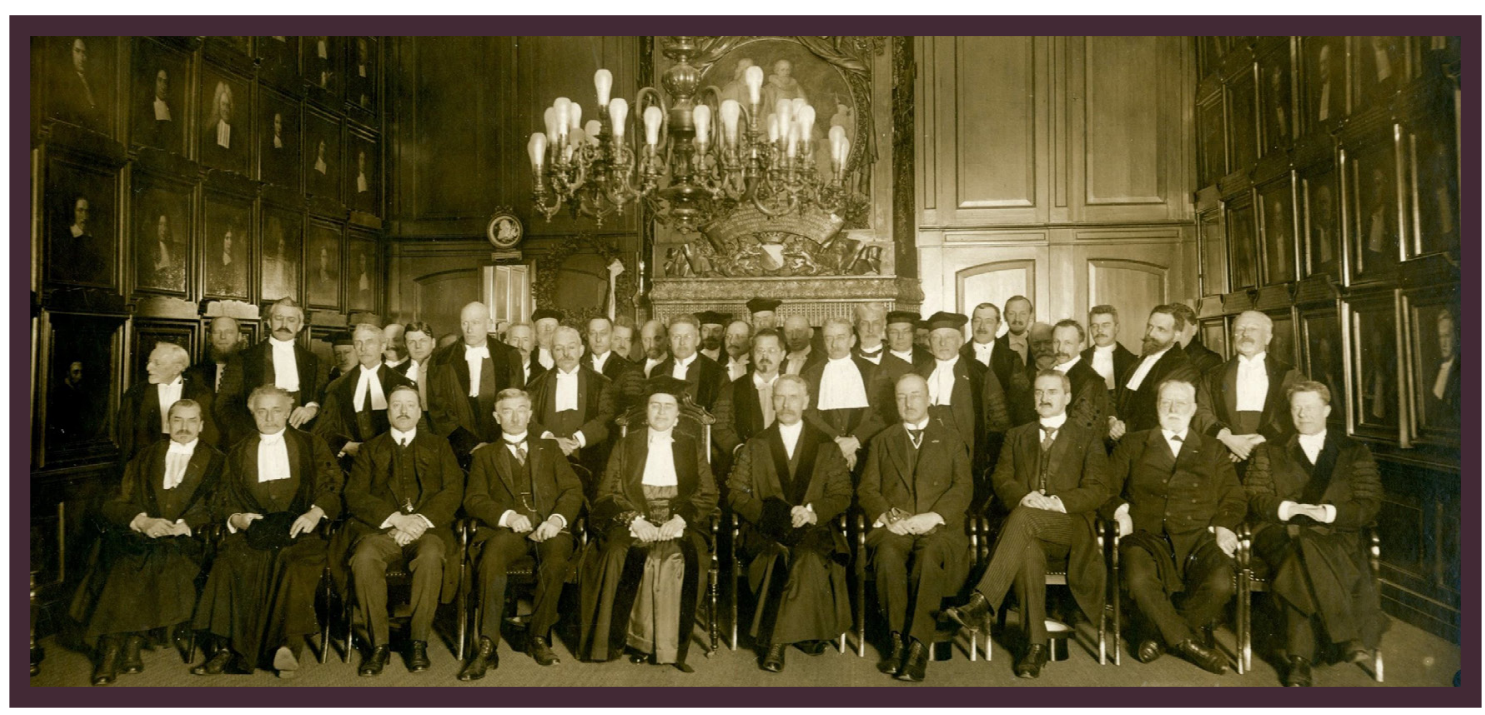

FIGURE 3 The professorship promotion of Johanna Westerdijk, 10 February 2017. Collection: The University of Utrecht Museum. 


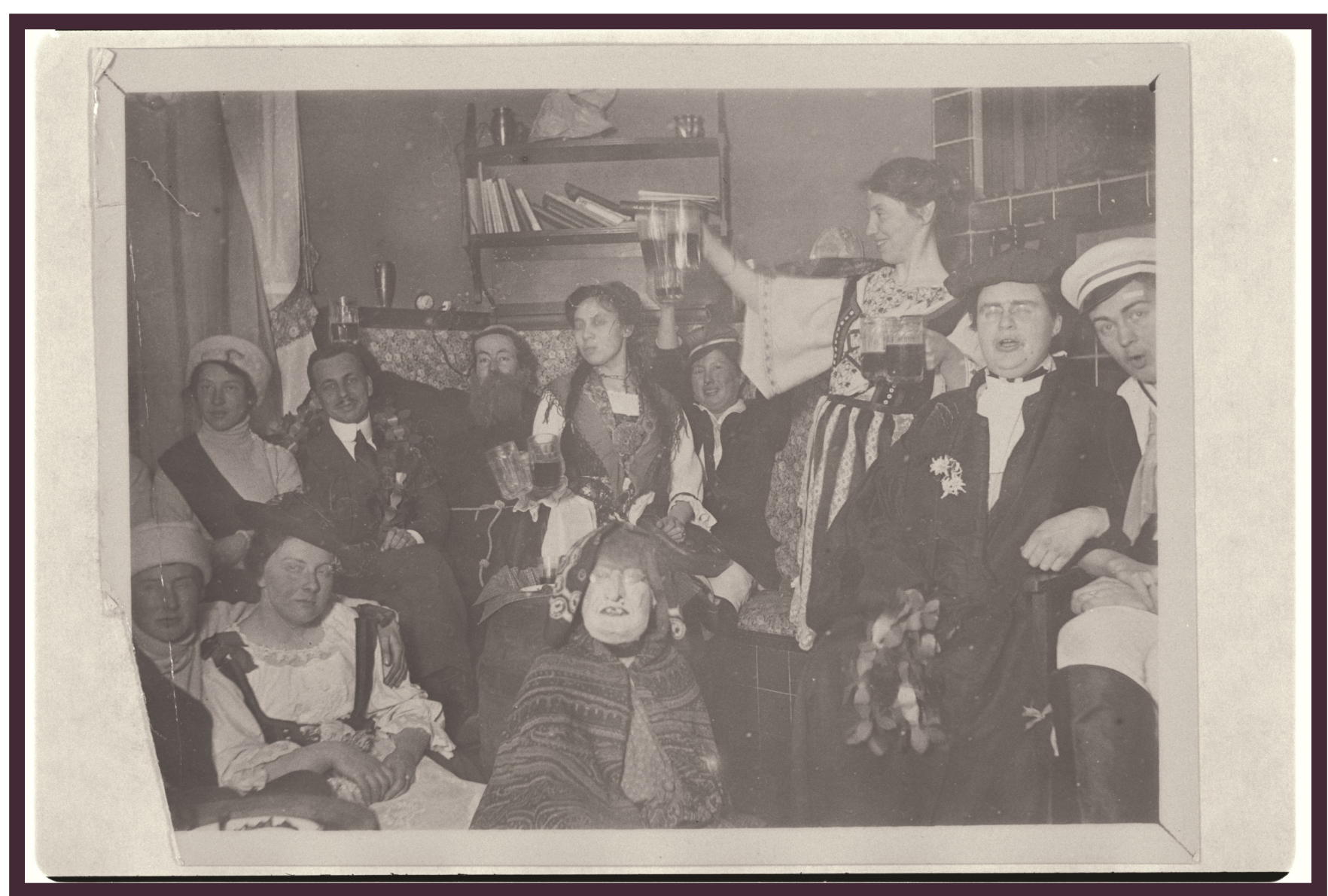

FIGURE 4 The celebration of Westerdijk's professorship, 1917,

Atria. The Institute on Gender Equality and Women's History in Amsterdam (100005718)

The usual accoutrements worn by Westerdijk for other solemn occasions also merit a discussion; for instance, her outfit during the farewell celebration of the conclusion of her university career in 1952. Westerdijk apparently wore a simple, long dress; however, close observation of preserved archival photographs reveals the original and effective elements of her outfit. The sleeves are particularly noteworthy - widened and elongated, cut at the elbow resulting in a falling sleeve forming a flower petal. In addition, the sleeves are elaborately designed with a bright ribbon, probably satin, classified by the characteristic gloss visible in the photo. Elegance distinguishes this outfit, which suggests that the Dutch researcher devoted special attention to this choice of apparel. 


\section{Focusing on the differences between the clothes worn by Westerdijk every day for her work and the ones worn during special circumstances is similarly important. For her, the workplace was not only her desk and the laboratory but also the garden and the field.}

Pictures showing Westerdijk seated behind the desk and working in the laboratory offer the impression of arranged portraits, some of which were published in the press. Nonetheless, one of Westerdijk's albums honouring the twenty-fifth anniversary of receiving her professorship also included photos depicting her behind the desk, in conversation with her pupils. This album evokes the personal nature of her character, and most likely represents a souvenir of sorts. Humorous captions also accompany the pictures, validating the private nature of the photo album. All the outfits in which Westerdijk appears in these photographs both formal and private - are similar. The appearance of the bottom part of Westerdijk's outfit remains unknown, as the photos only show her seated behind the desk. Nevertheless, the visible upper portion of her apparel confirms that her dress is simple yet elegant. These observations suggest that such types of clothing formed her everyday attire for work. In the case of official photographs, the professor would have devoted special attention to the selection of the right outfit. In similar clothing, she could be found in her laboratory, working with test tubes or a microscope. She wore outfits that were neither too unconventional nor adorned with exaggerated decorations. However, the simplicity of her clothing was often accompanied by subtle yet captivating details found at the neckline, button row, collar, and ties (Figure 5). She also worked in the botanical garden and the field in her usual dresses. In her 1937 portrait, we can see Westerdijk smiling from behind a shrub, attired in a blouse with a decorative froggy and a pattered cardigan. She wears a tiny necklace, while the scarf around her head is probably worn to avoid loosened hair by wind which would interfere with her comfort (Figure 6). Often, Westerdijk wore a long skirt, blouse, or coat in the field, making her outfits comfortable and suitable for fieldwork. 


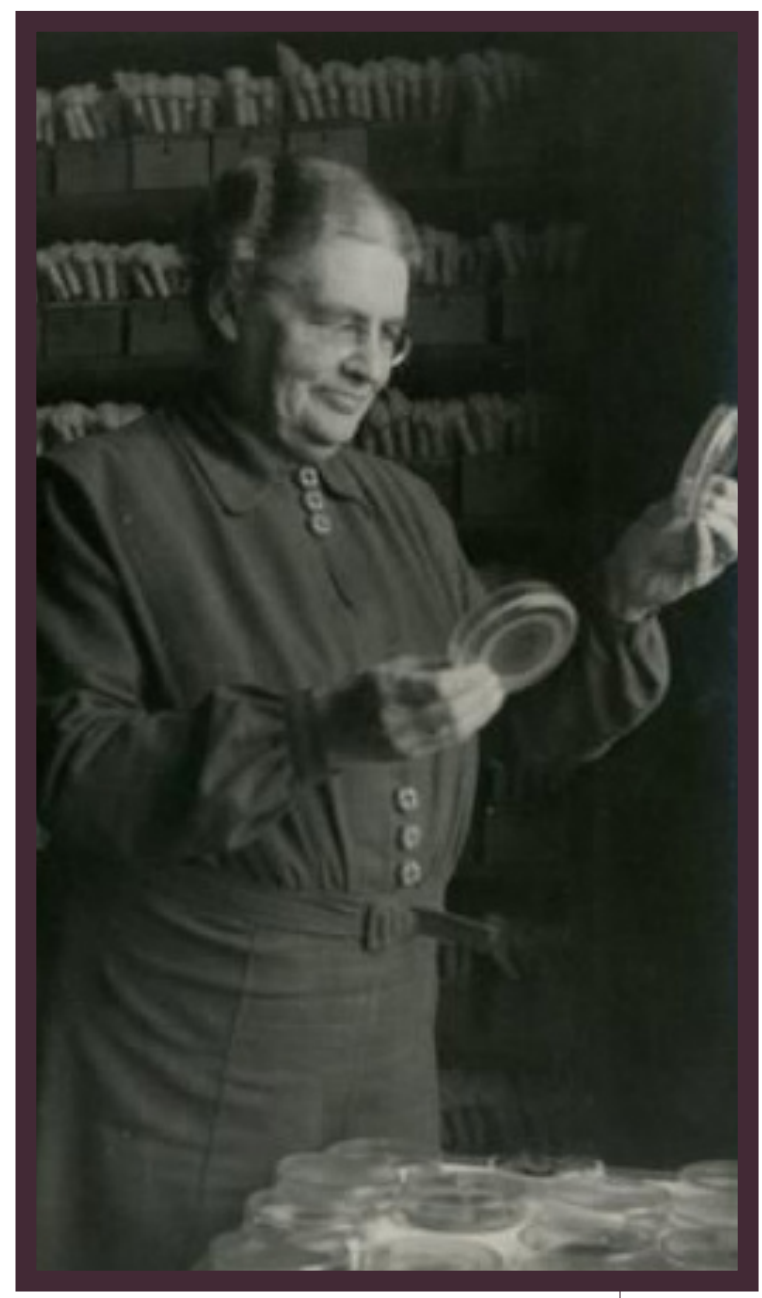

Interestingly, no picture of Westerdijk in a white coat has survived. In the photographs, the professor's mentees working in the laboratory in Baarn are garbed in laboratory coats - prescribed work uniform for the laboratory - but she wears her usual everyday dress (Figure 7). This fact can be interpreted in different ways. The lack of a laboratory coat may be a consequence of the professor's personal preferences. A lack of coat, especially in the later years of Westerdijk's career, may also emphasize her senior position. The laboratory coat was the uniform for an ordinary employee, which was not befitting of Westerdijk's post as the head of a research institute. In comparison, in a couple of the known pictures of the Polish and naturalized-French physicist and chemist Marie Curie-Skłodowska, she is seen posing in a laboratory in her working attire. Although the laboratory space highlights her position as researcher, she wears no lab coat but rather a simple, dark dress. Serious and modest outfits such as these were also worn by Curie-Skłodowska outside of her workplace, to highlight her position as a serious researcher rather than a wife and mother (Des, 2010, pp. 29-43). Perhaps Westerdijk, who remained unmarried, did not wish to mask her femininity with her dress yet, as with Curie-Skłodowska, whose laboratory space was enough to communicate her professional position.

FIGURE 5 Johanna Westerdijk, 1940-1952. Collection: The University of Utrecht Museum (0285-6449).

FIGURE 6 Johanna Westerdijk, 1937. Collection: Atria. The Institute on Gender Equality and Women's History in Amsterdam (100006021)

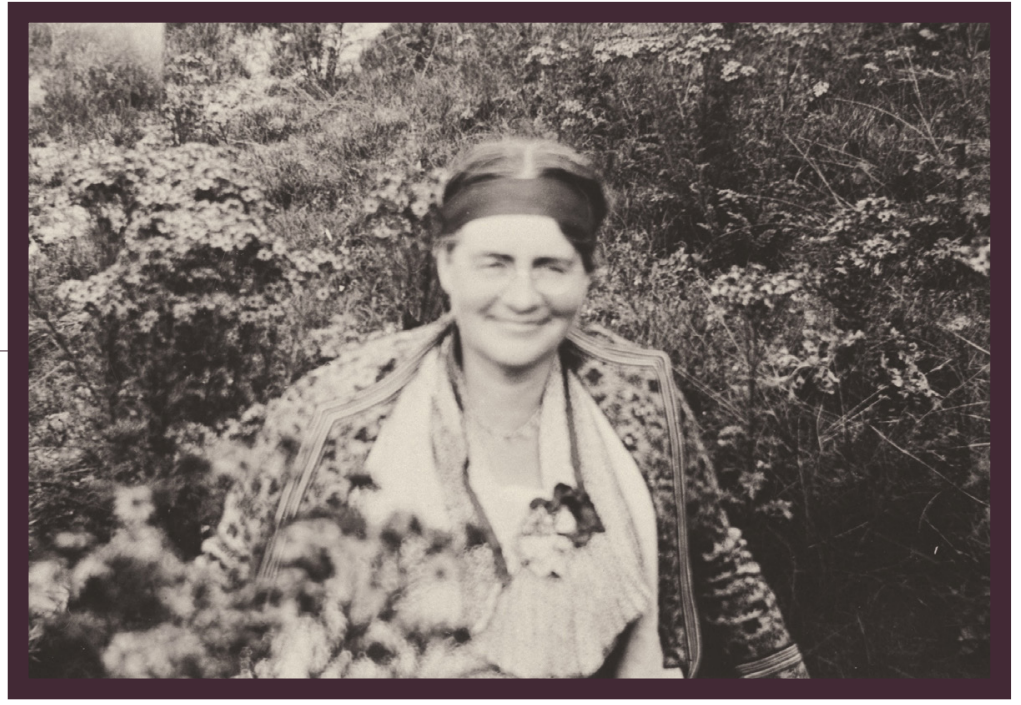




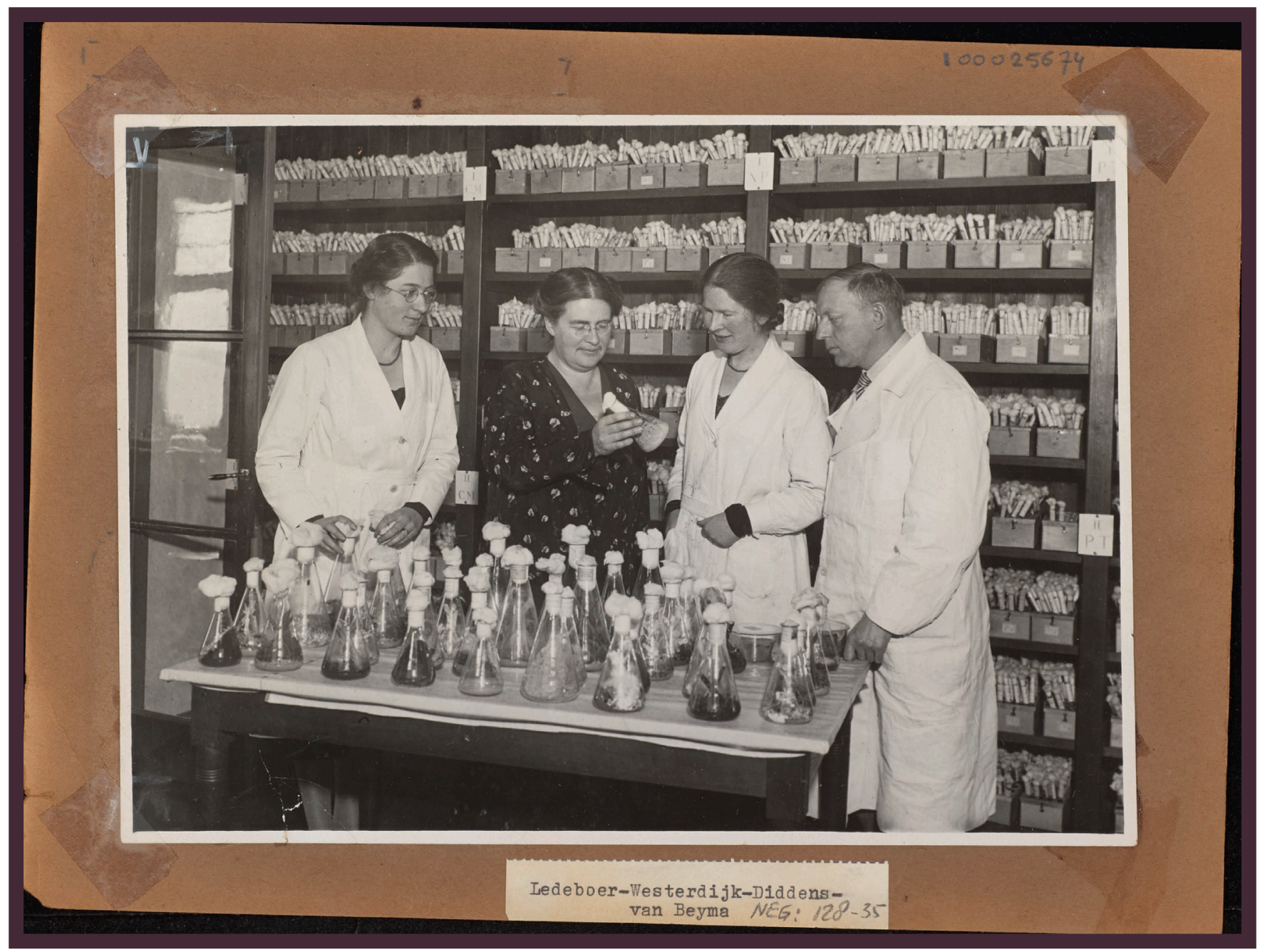

FIGURE 7 Johanna Westerdijk in the laboratory in Baarn, 1920-1952. Collection: Atria. The Institute on Gender Equality and Women's History in Amsterdam (100025674).

\section{LEISURE TIME AND TRAVEL}

Photographs from Westerdijk's foreign travels constitute an important source of knowledge about her attitude towards clothing. In her youth, she particularly enjoyed exploring mountains, evident in a photo from the collection taken in 1907, depicting a young Westerdijk treading the snowy landscape of Tirol in nearby Austria (Figure 8). Once she wrote about purchasing special clothing and equipment for mountaineering that she used for the excursion on the following day (Faasse, 2012, p. 62). This anecdote reveals a practical approach to her clothing, that it needed to be comfortable and suitable for the activity for which they were set aside. In the photograph, Westerdijk wears clothes already adapted by women for hiking in winter - a warm, long skirt, jacket, hat, gloves, walking stick, sturdy shoes with a flat bottom, and a rucksack. Both the activity and the appropriate garments were relatively new customs in this era. In early twentieth-century Europe, trousers were not an easily accepted element of women's clothing, even out of other people's view in the mountains, or during other outdoor activities. The photo shows the subject wearing a typical mountain-hiking outfit, as described in textbooks (Klemensiewicz, 1913, pp. 21-48). In contrast, some women used to explore mountains in corsets and high heels. 


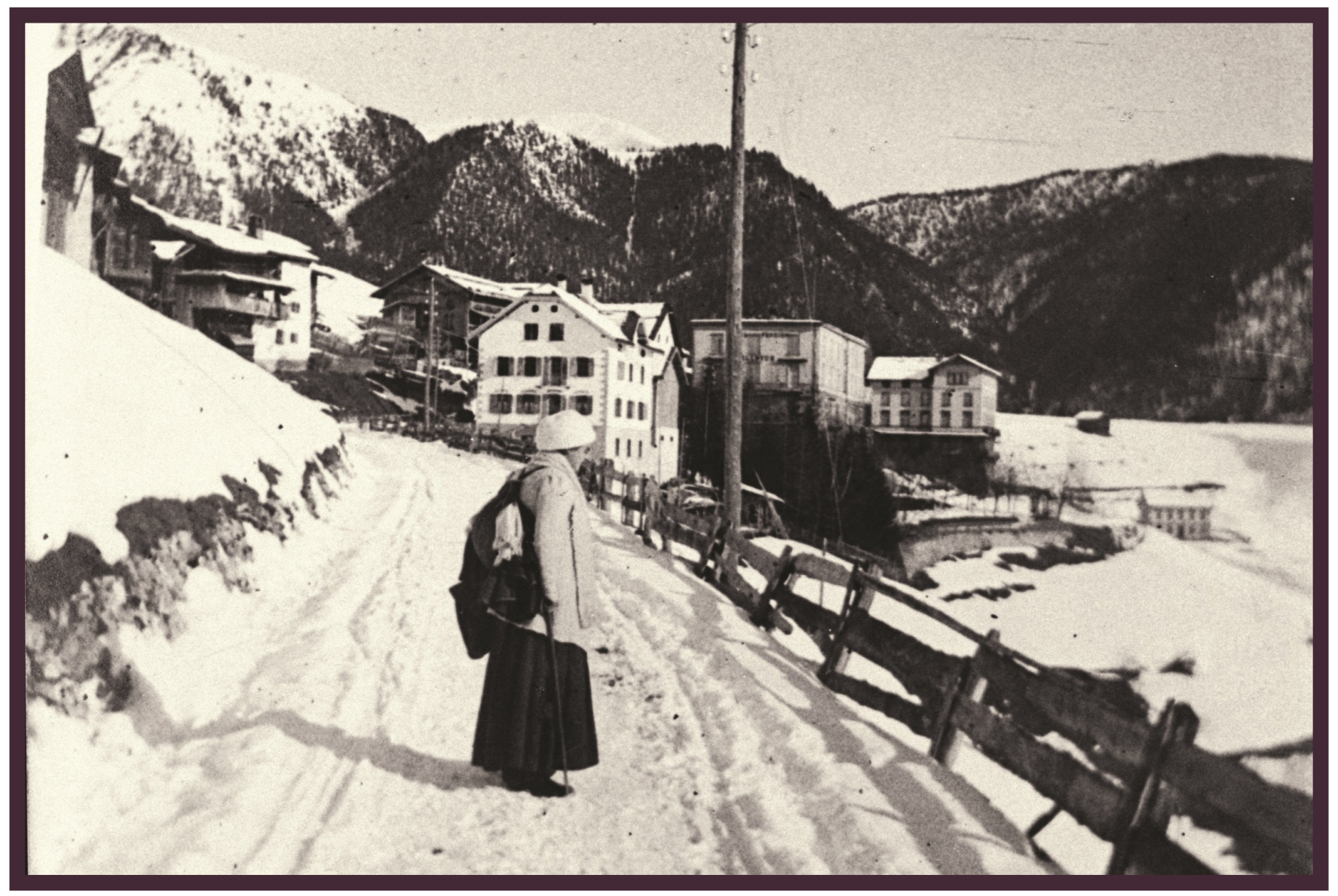

FIGURE 8 Johanna Westerdijk in the mountains, 1907. Collection: Atria. The Institute on Gender Equality and Women's History in Amsterdam (100005985).

Westerdijk's collection also includes several photographs of her bicycle tours. A photo taken in 1906 shows her riding with her female friends, all of whom wore long skirts, probably the divided ones meant for cycling and horse riding. However, these were quite difficult to distinguish from the usual skirts (Coppens, 1996, pp. 64-65; Van Godtsenhoven, 2012, p. 106). This identification is especially challenging in the case of this photograph of Westerdijk with her friends due to the small image size. The women are standing next to their bicycles, so the parting, indeed present, is invisible. During another ride with friends in 1917, Westerdijk is seen accompanied by two women and a man. Both Westerdijk and the other women present in the picture can be seen in bloomers, which cover their legs up to half of their calf. The cyclists wear comfortable flat shoes and head coverings, most probably meant to protect them from the sun (Figure 9). These aspects of their outfits again reveal a pragmatic approach to clothing. Over the white blouse, Westerdijk is also wearing a short coat, which seems to be a cover for the upper half of her body from prying eyes, serving a practical purpose. For her 1906 photo, Westerdijk could also have chosen to wear bloomers, but it would have caused a scandal at the time (Smith \& Greig, 2003, pp. 161-163). In this case, Westerdijk decided to follow the trends in sport fashion and in doing so, made sure to not stand out among her female friends. 


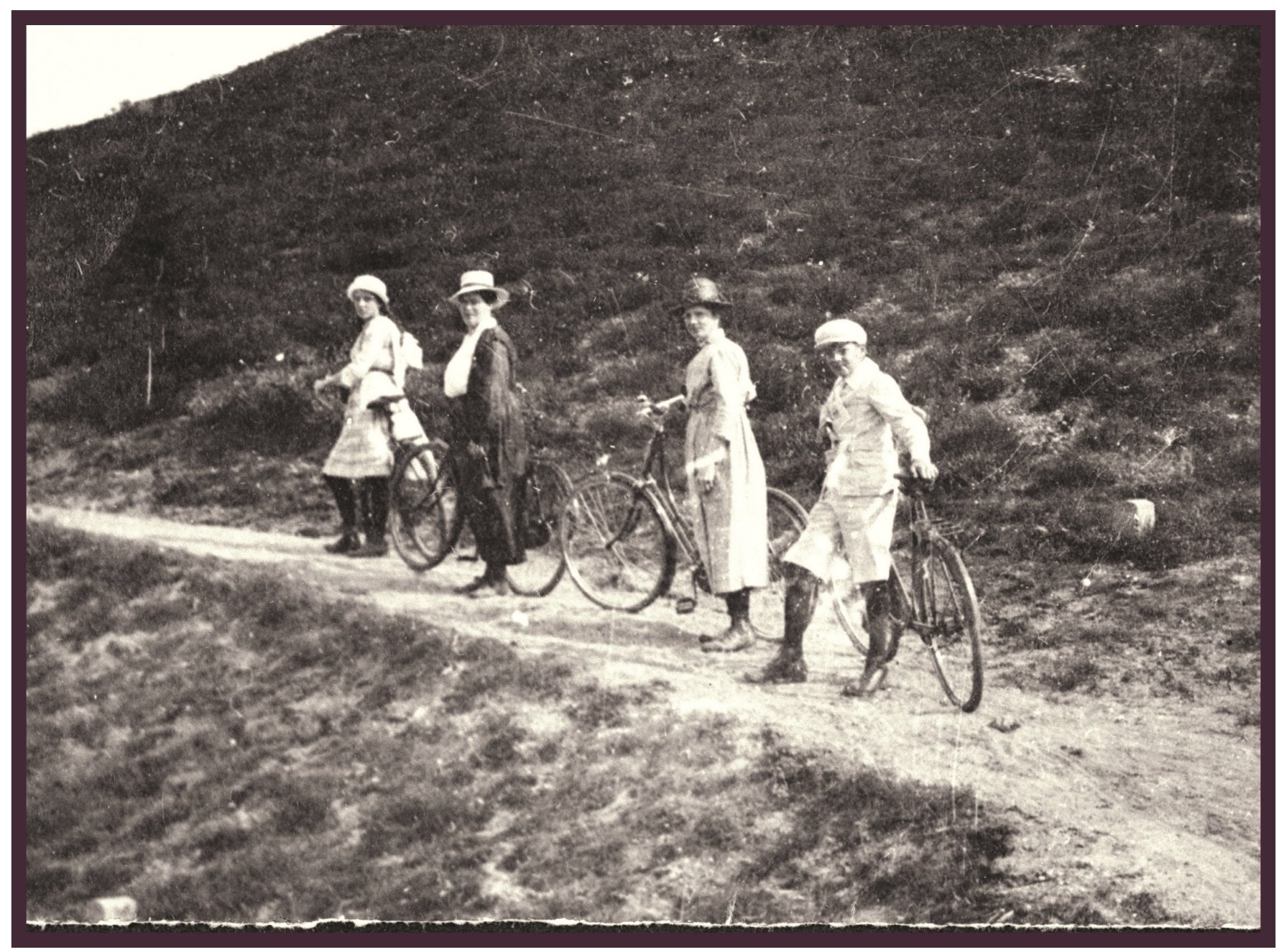

FIGURE 9 Westerdijk with her friends, 1917, Collection: Atria. The Institute on Gender Equality and Women's History in Amsterdam (100006004).

Westerdijk's trips to Asia and the US in 1914 are immortalized in more than a dozen photographs. One picture shows her in a two-piece dress, a straight-cut light sweatshirt, buttoned at the front, and pants with simple soft hat on her head. Her ensemble was probably originally a men's outfit but exudes a sense of comfort and appropriateness for travelling and field research. The photo was taken shortly before the Great War, during which trousers became a more acceptable element of women's attire, at least for those who engaged in traditionally male-dominated work (Bass-Krueger \& Kurkdjian, 2019, pp. 218-237). Another photo from the trip shows Westerdijk in the same clothing, on a horse (Figure 10). In the photograph, Westerdijk acts as a man, wearing the same jacket, pants, soft head covering, a scarf under her chin and high, riding boots while riding the horse astride. Right behind her is another woman riding side-saddle in her feminine attire. At the back end, four other women are standing in feminine outfits. At first glance, Westerdijk may appear to be one of the men, also present in the photograph. The picture raises a question surrounding the extent of the shock Westerdijk's fellows may have felt seeing her in trousers. At the time, American society recognized women wearing trousers; even as the dress reform movement was already in decline and nearly forgotten, it did influence the changes in fashion that occurred between 1900 and 1914 (Fischer, 2001). 


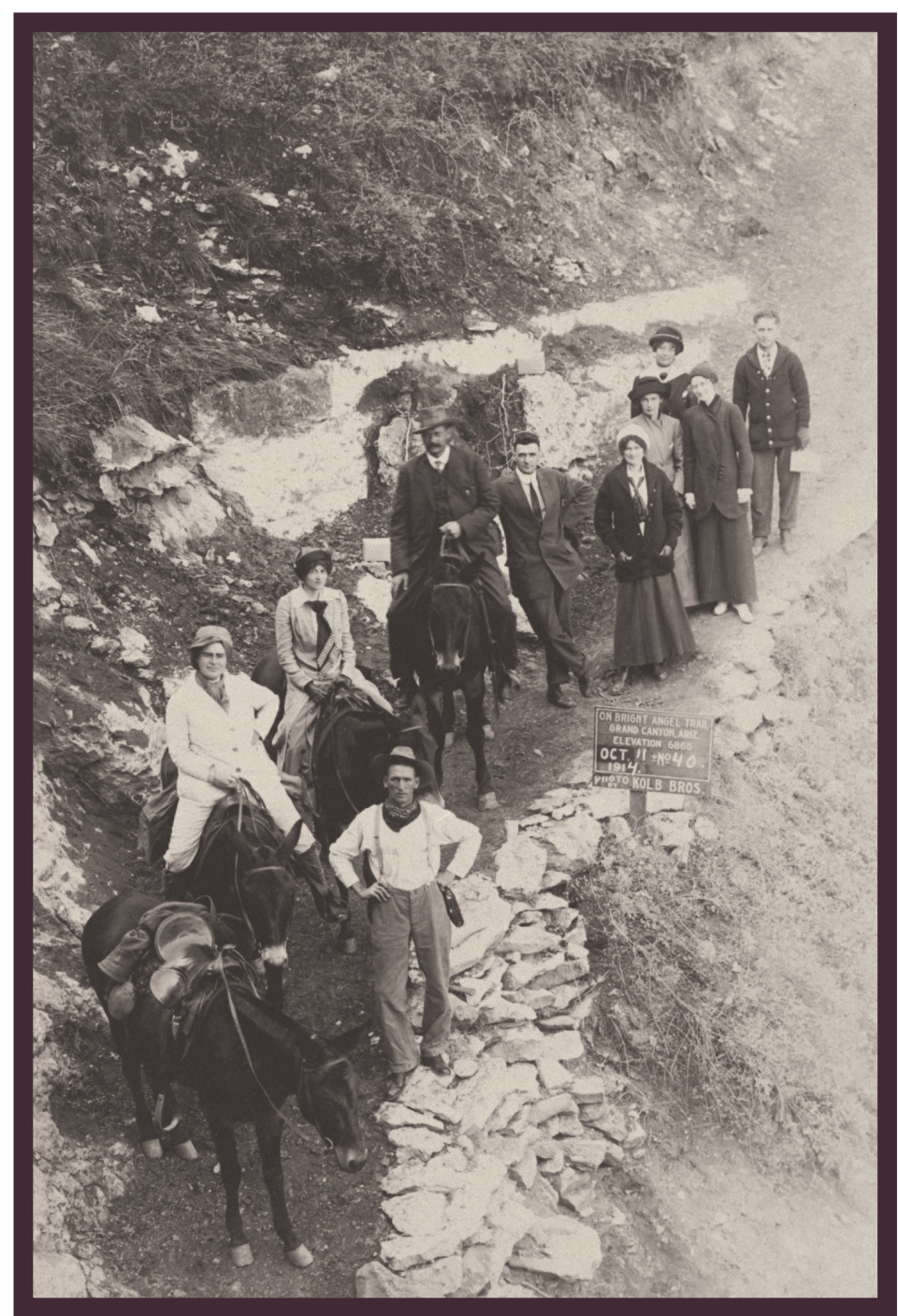

However, Westerdijk was the only woman in the company who opted to wear trousers during the excursion. No other similar photographs of her (i.e., wearing such trousers) taken in Europe are available. The inference is that Westerdijk decided to wear trousers in the US because she found herself outside her usual social context and in an environment where the idea was socially more acceptable than in Europe.

This masculine outfit worn by Westerdijk was not consistent throughout her travels. Several other photos from the US show her in a long skirt, long-sleeved blouse, and a hat. However, except the skirt, her overall appearance is quite masculine. On the contrary, a photo taken in Mexico depicts Westerdijk in a typically feminine and quite elegant outfit - a light, long-sleeved blouse with a wide collar decorated with a dark bow, with a broach fastened under the neckline. She also wears a very thin, long neck-chain, barely visible on the bright blouse. She is seated somewhere in a field, allowing us to notice that she wears a white underskirt below her long, striped skirt and comfortable flat shoes. Her head is protected by a dark hat with a slightly rolled up brim and a large floral decoration that stands out for its bright color (Figure 11). A hat was often found resting on Westerdijks head, which was necessary during field research. During her trip to Japan, Westerdijk wore a light, white travel suit. Her clothing choices during her travels illustrate her preference for comfort, yet the aesthetics of her outfits could vary between masculine clothing to feminine ensembles. 


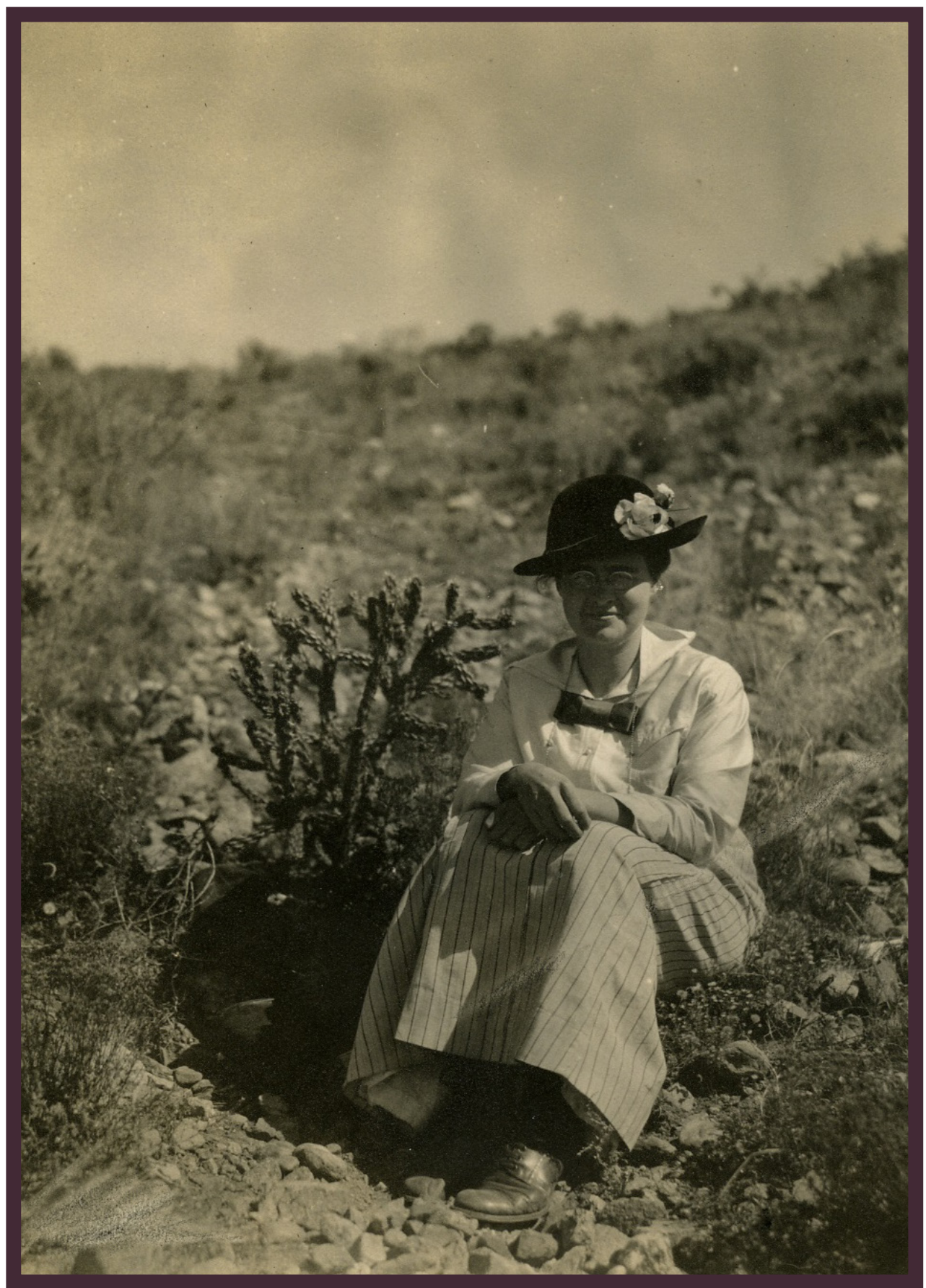

FIGURE 11 Johanna Westerdijk in Mexico, 1914. Collection: Atria. The Institute on Gender Equality and Women's History in Amsterdam (100027422).

\section{DRESS AND PERSONALITY}

In the following paragraphs, Westerdijk's practices of self-fashioning, costume-wearing and cross-dressing serve to delve into changes in her character, both in personal and professional capacities. 


\section{Clothing can be understood as mirroring Westerdijk's approach to womanhood, ageing, her relationship with other people, and her own position in a male-dominated, academic world.}

\section{APPROACH TO FASHION}

The extent to which Westerdijk followed the latest fashion trends constitutes another key question regarding the connection between biography and clothing. A comparison of the changes in Westerdijk's personal clothing style to the fashion developments during her lifetime is one means of answering this question. One of the oldest preserved photographs of Westerdijk was taken some time in 1905 (Figure 12), depicting a young woman alongside her siblings. The photograph was certainly taken in the atelier, so the members of her family had carefully chosen their outfits. The three sisters are seen wearing rather narrow blouses or dresses compared to the previous decade with a high stand-up collar and only slightly wrinkled sleeves. All the upper parts of their clothing are made of sophisticated fabrics, decorated with elements of lace, pleating, and embroidered matelassé; the brother wears a dark suit with a tie. These elegant outfits meet the fashion requirements of the time, and this characteristic exemplifies the privileged social strata to which Westerdijk's family belonged.

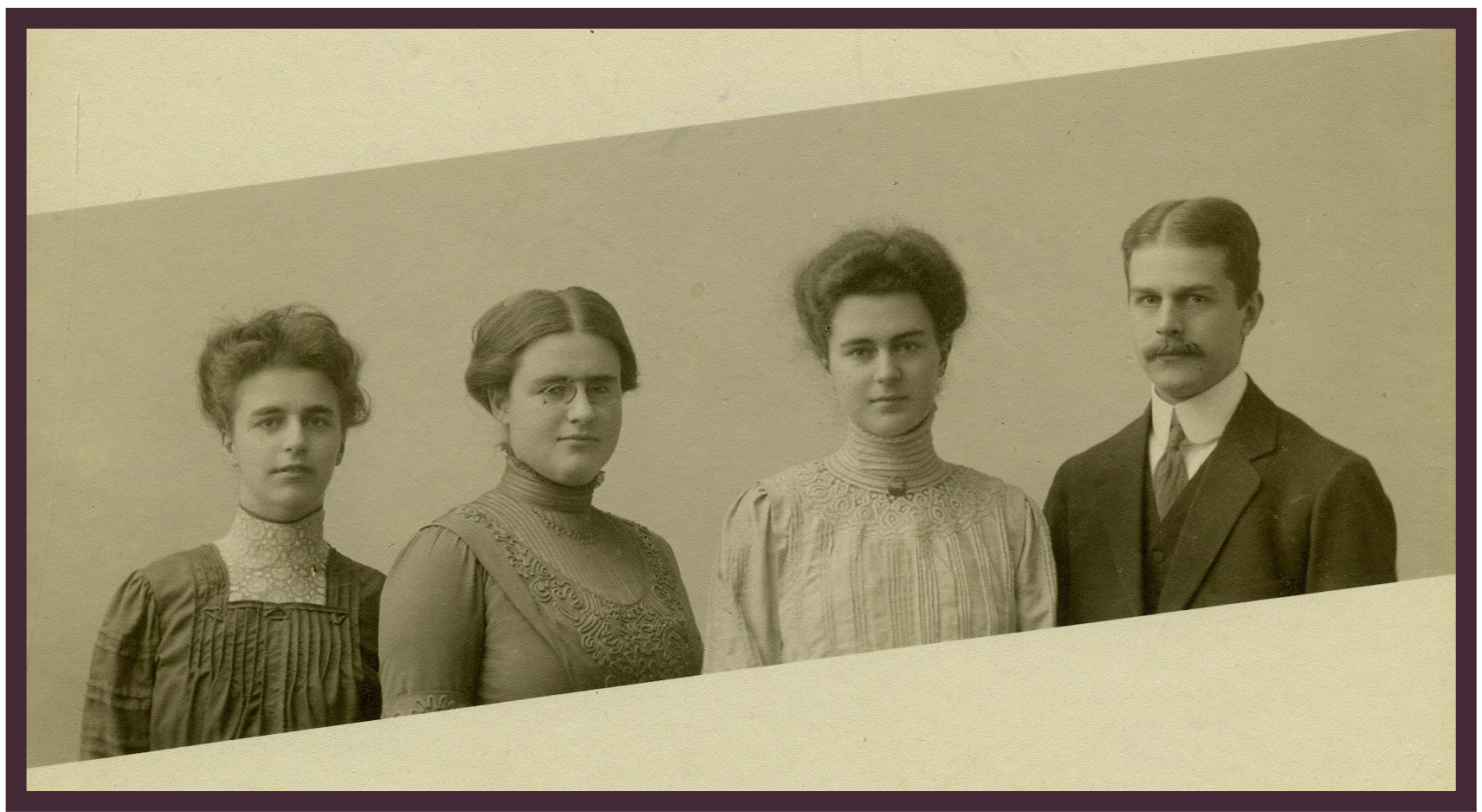

FIGURE 12 Family Westerdijk, 1905. Collection: Atria. The Institute on Gender Equality and Women's History in Amsterdam (100027418). 


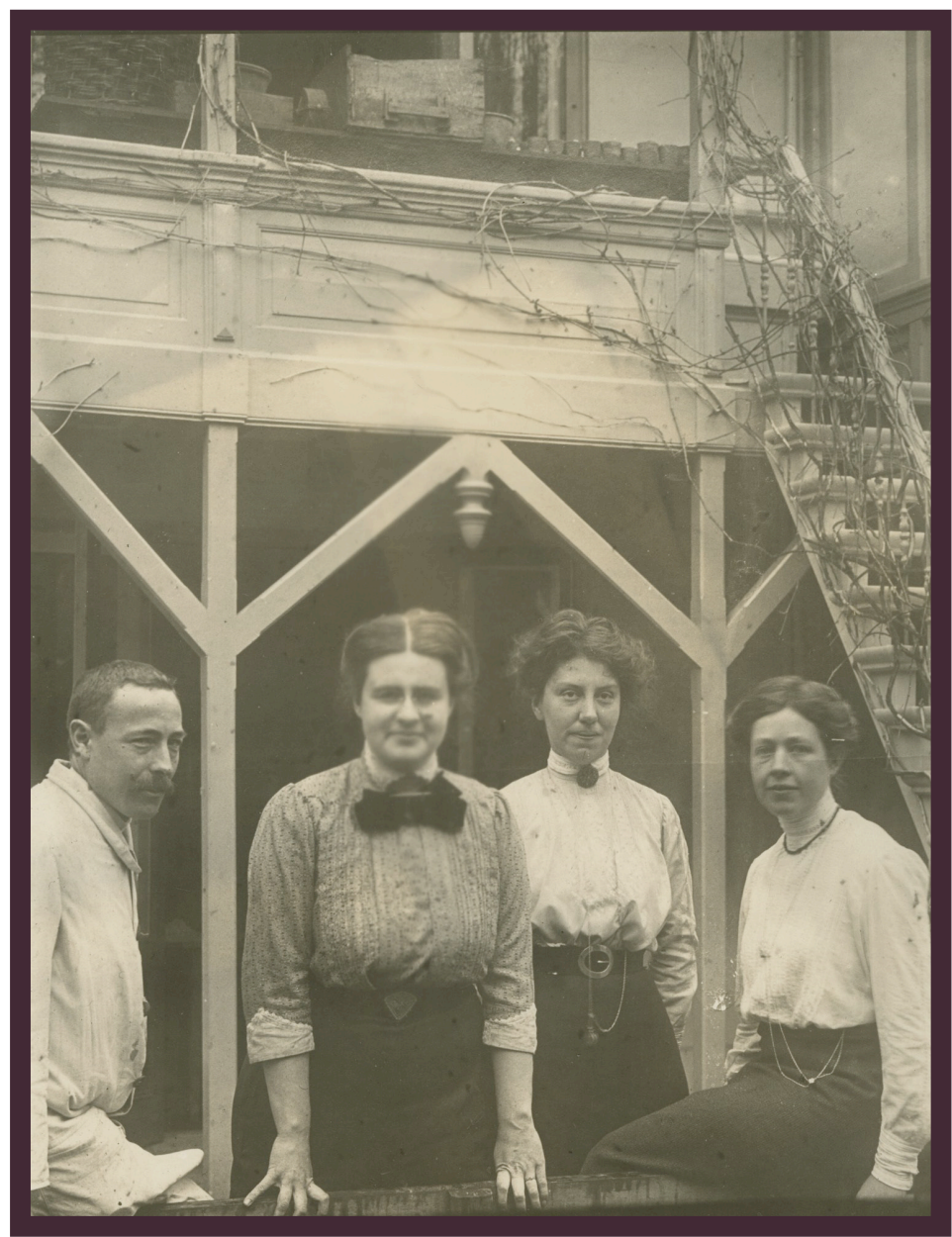

FIGURE 13 Johanna Westerdijk and two unidentified women, 1900-1910. Collection: Smithsonian Institution Archive.

Several photographs from the period of Westerdijk's studies in Amsterdam have survived. The first years of the twentieth century, a period when Edwardian fashion dominated Europe, were characterised by an S-bend silhouette, large hats, abundant lace, and decorations and puffy sleeves (Evans, 2013, pp. 43-60). In addition, the corset was a mandatory part of this outfit, which gave the female figure a specific shape (Steele, 2001, pp. 147151). However, Westerdijk chose a slightly different attire than set by these trends in upper-class spheres, dressing instead in apparel usually worn by women from the working class. Her elegant, yet rather modest outfits usually consisted of a long skirt (Wilson \& Taylor, 1991, pp. 68-71). In a photo with two other unidentified women, Westerdijk wears a patterned blouse with half-sleeves, buttoned at the front with a collar and a dark bow below (Figure 13). A couple of pictures from the first decade of the twentieth century depict Westerdijk in hats of relatively small sizes, rather than the huge, extensively decorated ones that dominated fashion from 1907, reaching its peak between 1910-1912 (Evans, 2013, pp. 32-33). This choice of accessories confirms her interest and following of the fashion trends - but only to a certain point. 
Westerdijk opted for clothing worn by women who either lacked sufficient resources or preferred freedom of movement from the corset. Did Westerdijk herself wear a corset? The alternatives for corsets in the form of bust supporters (a type of brassiere) already existed in the beginning of the twentieth century (Cunningham, 2003, p. 85). A few women decided to abandon the corset, but some of them used both the corset and the bust supporter, depending on the circumstances. As for Westerdijk, she might have worn a corset for the photograph with her siblings - the type of tight blouse she wore required one during the period. On the contrary, the wider and looser blouses and long skirts she dressed in later could be worn with a brassiere.

Among the women who deferred following the newest fashion trends were indeed often students and scholars, active women, social activists, and feminists. A comparison of Westerdijk's clothing to the outfits of other European students from this period, including those who appear in her photographs, indicated that she did not deviate from the norm in this sense. The exception were Russian students whom Westerdijk met in Zürich. Inspired by nihilism, Russian students in Switzerland wore very casual clothing and their hair short (Freidenreich, 2002, p. 11). Westerdijk hardly succumbed to similar influences in everyday life, and the long skirt and blouse remained her favourite items of clothing at least until 1920. Unfortunately, no photographs of Westerdijk from the 1920s have survived. This deficit is significant because it hinders the reconstruction of her reaction to the change in the length of women's clothing or the emergence of short haircuts that emerged across the decade.

In the 1930s, longer skirts and dresses became fashionable again and the waistline returned to its natural place (Fukai, A. \& Suoh, T, 2012, p. 120), and Westerdijk's garments from the decade also met the fashion requirements; however, her clothing was looser than the usual close-fitted feminine outfits of this period. In the subsequent decades, her style did not undergo any noticeable changes. Perhaps the world of science, and her constantly developing intellectual pursuits, pushed matters of fashion to the background. However, this attitude does not signify a complete lack of interest in elegant clothes or being chic - good quality fabrics, fancy patterns, attractive details, and delicate jewellery characterized her simple outfits (Figure 14 and Figure 15). 


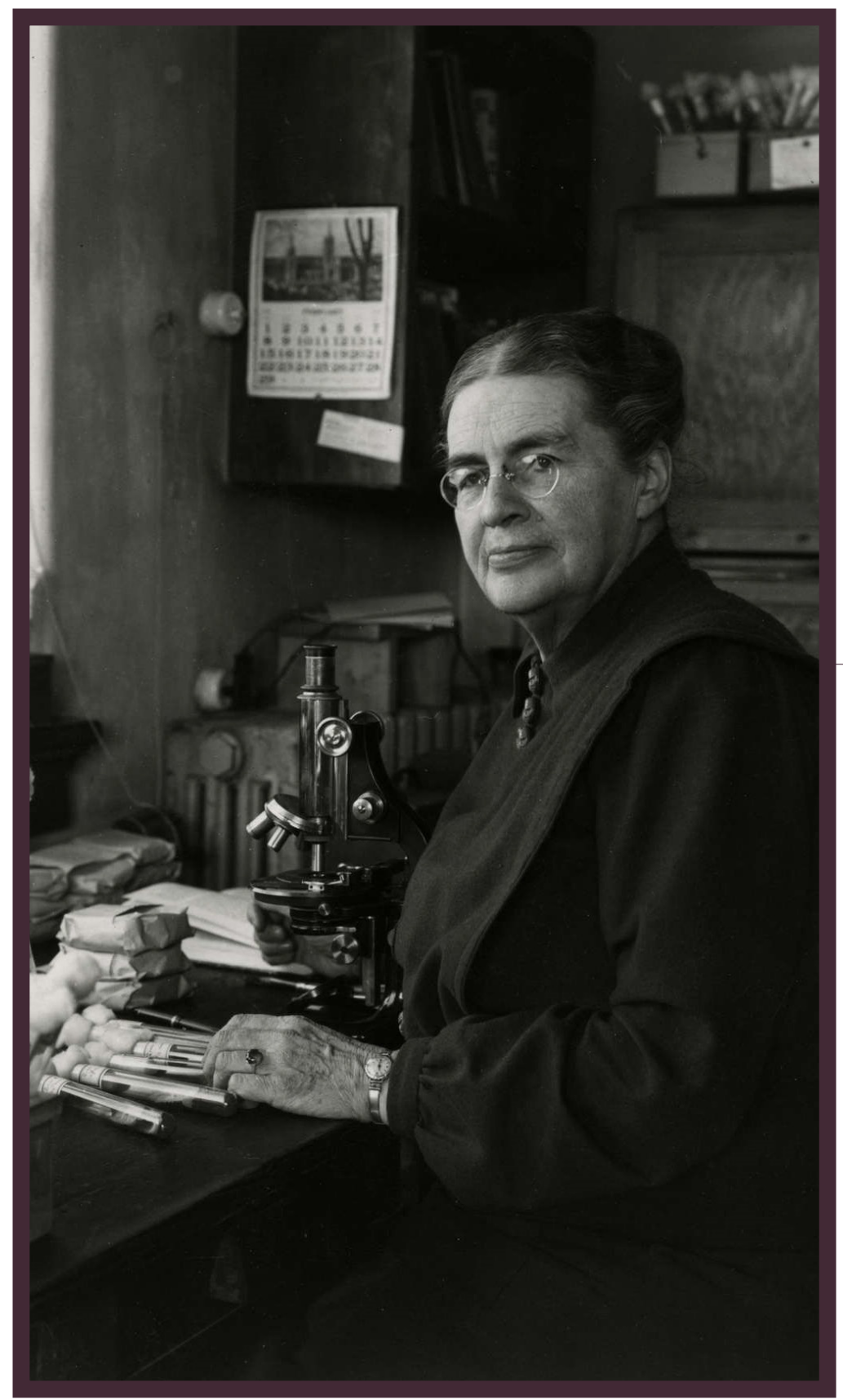




\section{People may deny their interest in fashion, but they always make a choice about what they adopt or reject for their own clothing and appearance.}

\section{PERSONAL STYLE}

The characteristics of Westerdijk's personal style are also essential. First, personal style should be differentiated from an approach to fashion, for an individual's clothing may change due to fashion innovations, but changes in personal, professional, or financial situations may also transform one's attire. Moreover, people may want to adopt their own style, keeping with the changes occurring in their body shapes. Observing whether someone's clothing changes or remains the same is essential in the context of the development of their lives and personalities.

In the case of Westerdijk, the uniformity of her clothing is striking; its style is consistent, almost unchanging. Westerdijk was particularly consistent in her hairstyle in all of the images - a middle part, usually pulled back smoothly and braided (Figure 16, Figure 17, and Figure 18). This choice can be attributed to various factors. The smoothly combed hair pinned at the back seems comfortable for her work. Her coiffure was also fashionable in her youth, when she was may have been more interested in following fashion trends. Westerdijk later disregarded the necessity of styling her hair according to modern hairstyles. It is important to notice that the preferable coiffure of Westerdijk, as well as being comfortable, also emanated elegance that lended her a respectable allure. Therefore, her unchanging dress style can be also considered a quest for serious assessment by her colleagues. 


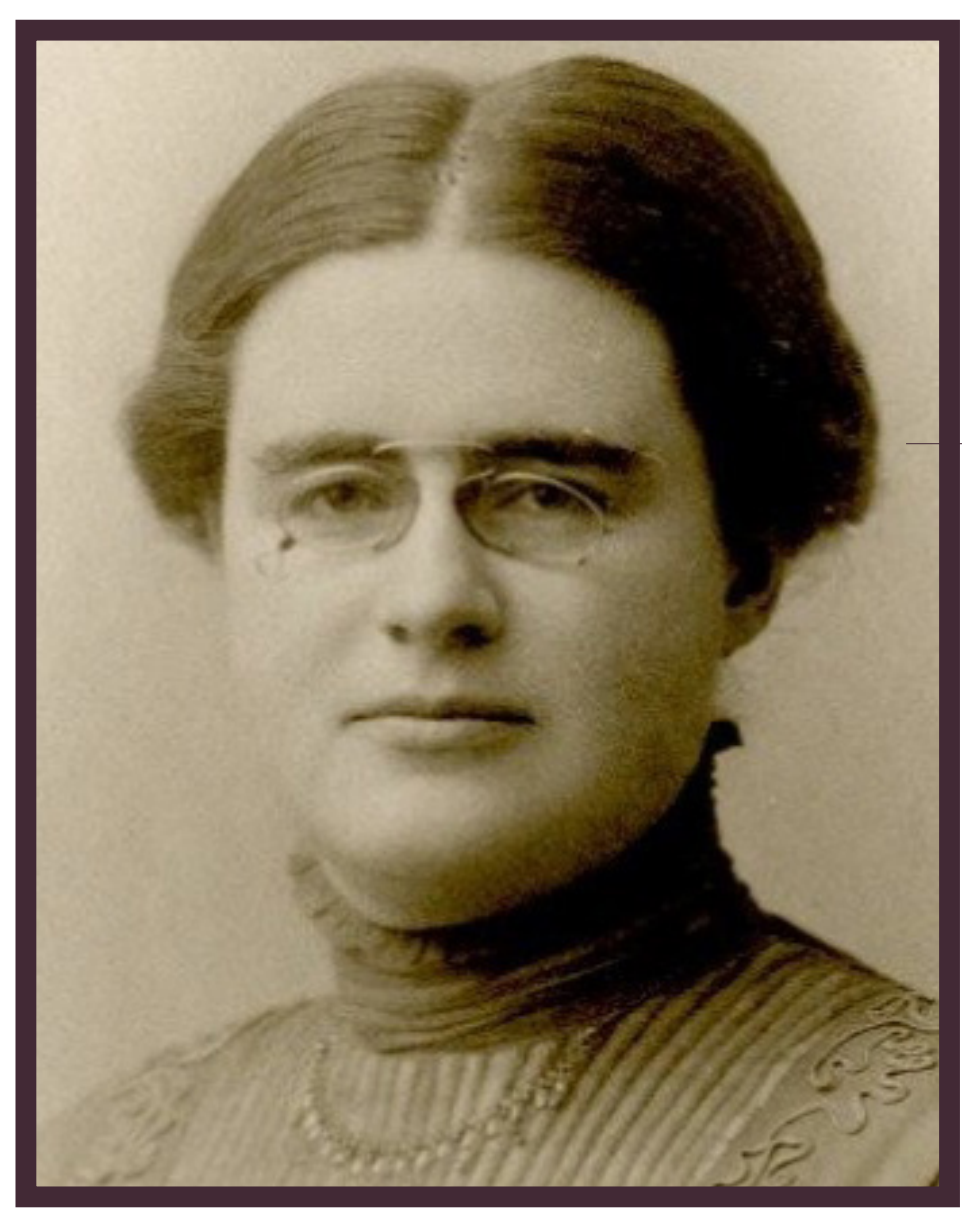

FIGURE 16

Johanna

Westerdijk

1910s. Collection:

University of

Utrecht.

FIGURE 18

Portrait of

Johanna Westerdijk, 1940-1952

Collection: Atria.

The Institute

on Gender

Equality and

Women's History

in Amsterdam

(100006149)

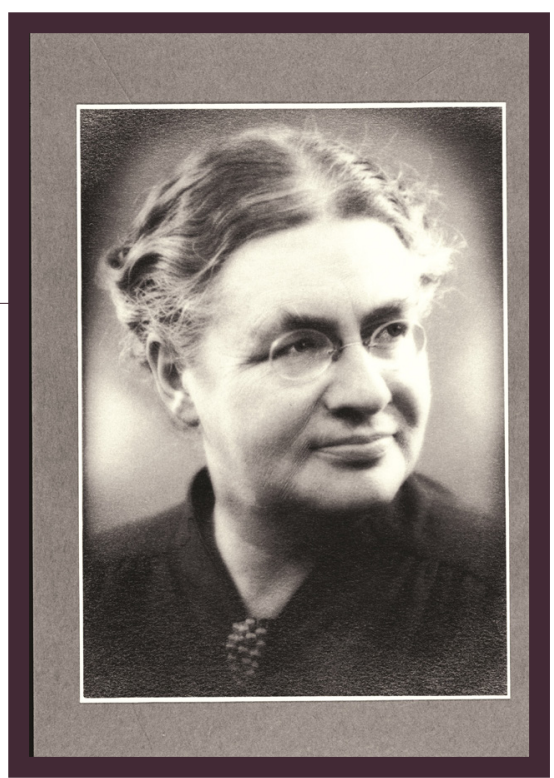

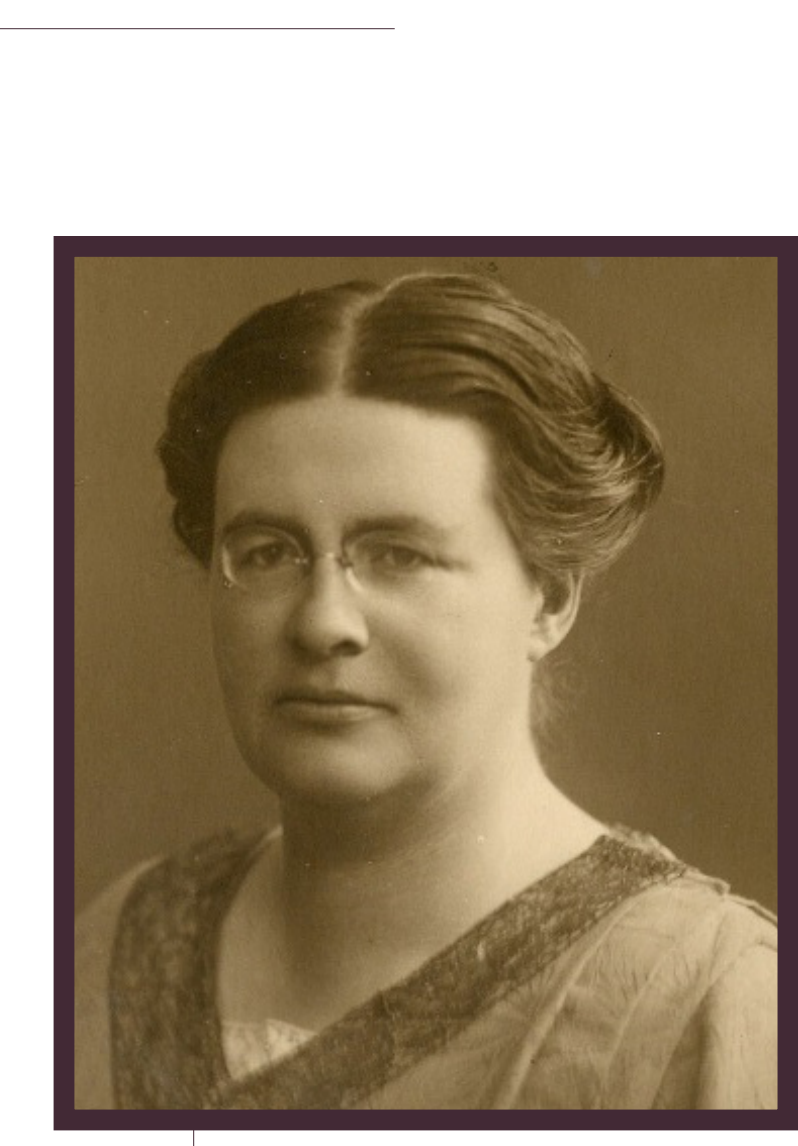

FIGURE 17 Portrait

of Johanna Westerdijk

1930-1940. Collection:

Fidel Carl Albert Greiner,

Amsterdam. 
Clothing certainly reflects one's origins, character, and occupation, therefore, its more or less constant nature may signify slow change or that one's goals remain unchanged. This interpretation seems fit in reference to Westerdijk, who was highly consistent in following her chosen career path in science.

From the beginning of the 1930s, her sartorial sense became quite characteristic loose, mismatched, and long styles dominated the scholar's wardrobe (Figures 19 and 20). Perhaps Westerdijk, entering adulthood, had found her preferred clothing and did not feel the need for significant changes. Nonetheless, another issue that cannot be overlooked is that Westerdijk wore plus-sized clothing, and this fact certainly influenced her style. Such outfits also provided comfort, including flat shoes that are evident in numerous photos, regardless of place and circumstance. The look that Westerdijk had chosen after reaching middle age could be a result of adopting the culturally accepted appearance for mature and older women, which included increased covering-up and self-effacing aspects (Twigg, 2014, p. 148). This behaviour can be understood as a fashion statement as well; that is, interest in fashion can be expressed in the need to look "normal" and not to stand out (Hollander, 2009, pp. 364-365). Westerdijk, who believed in standing shoulder to shoulder with her male colleagues in

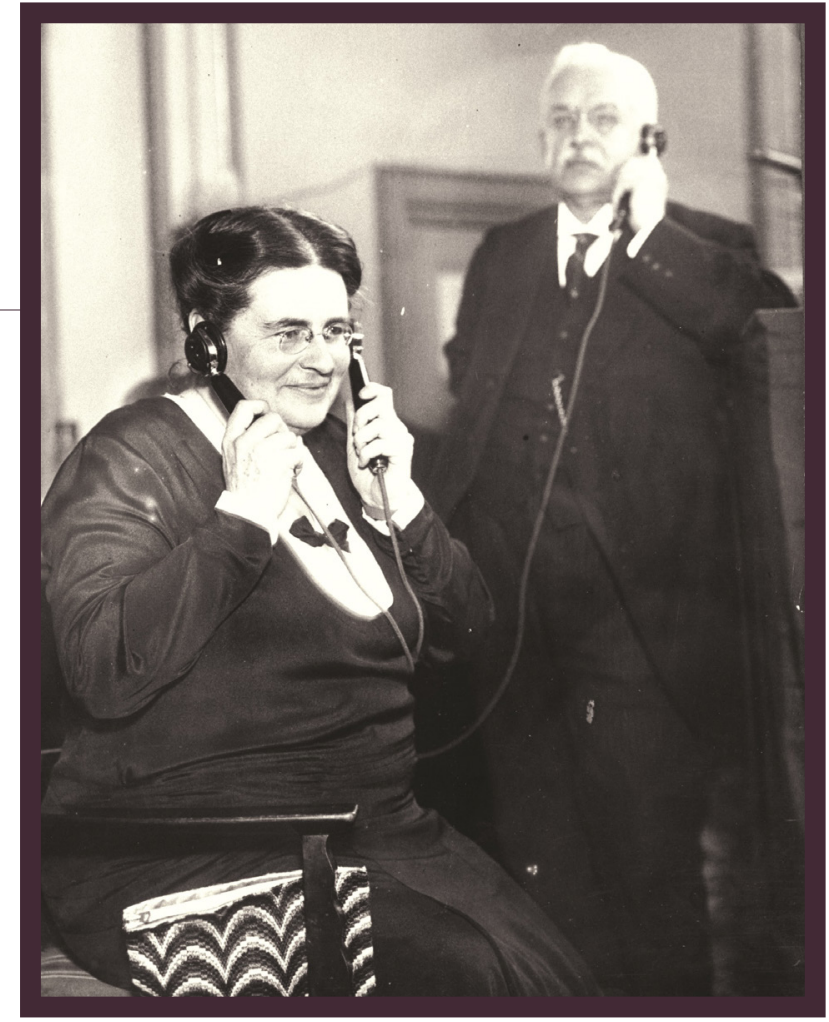

terms of quality of work (Bosch, 1994, p. 402), might have also wanted to highlight her seriousness by wearing dresses appropriate for her age and social position.

A thorough analysis of her clothing reveals some of the Dutch researcher's preferences. She gladly wore both plain and patterned fabrics, with flowers as a recurring motif. In one of her later photographs, she is seated in front of a group wearing a loose, long dress patterned with large light flowers in contrast to the darker background. Other women present in the photos can also be seen wearing dresses made of fabrics with floral patterns, revealing that Westerdijk was not indifferent towards specific trends (Figure 20). On the other hand, the floral motif also appears in Westerdijk's clothing in the form of brooches. This choice could be due to her scientific interests but is unconfirmed in her written statements. 


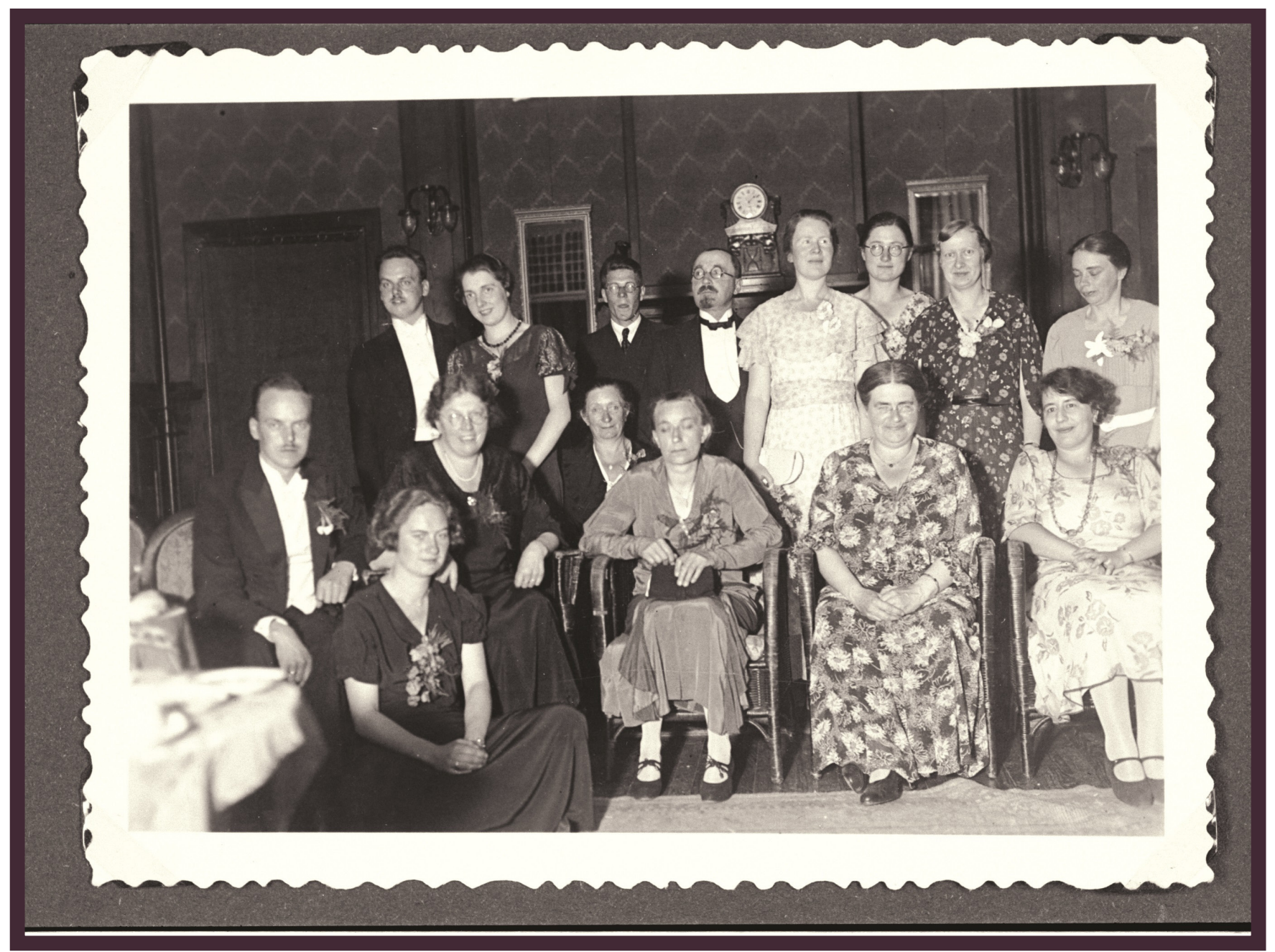

FIGURE 20 Group portrait, 1940-1952. Collection: Atria. The Institute on Gender Equality and Women's History in Amsterdam (100005968).

\section{COSTUME WEARING AND CROSS-DRESSING PRACTICES}

Johanna Westerdijk's unusual clothing habits included wearing costumes and cross-dressing. The Dutch professor loved music, parties, and theatre (Zadoks \& Van Bruggen, 2008, p. 16; Pegtel, 2018, p. 101). Westerdijk's photographic collection contains several images of performances, some of which were organized in her honour, for example, on the occasion of her first receiving the professorship, where she is in her academic gown. In a photo taken a year later, Westerdijk is surrounded by a theatre group, while also wearing a costume herself. It is worth noticing that the outfits and props are visibly inspired by the seventeenth century Dutch genre paintings (Figure 21). Regrettably, it is unknown whether the costumes were meant for a play or only for this picture, yet it is obvious that the group is having a cheerful evening and everyone, including Westerdijk, seems to be enjoying the costumes. Her appearance as surrounded by her students in this photograph reflects her relationship with them. When work was over, or someone's graduation came about and there was reason to celebrate, the students became her colleagues. The costumes demonstrate the changed relationship from dependence to demonstrate one of equality. 


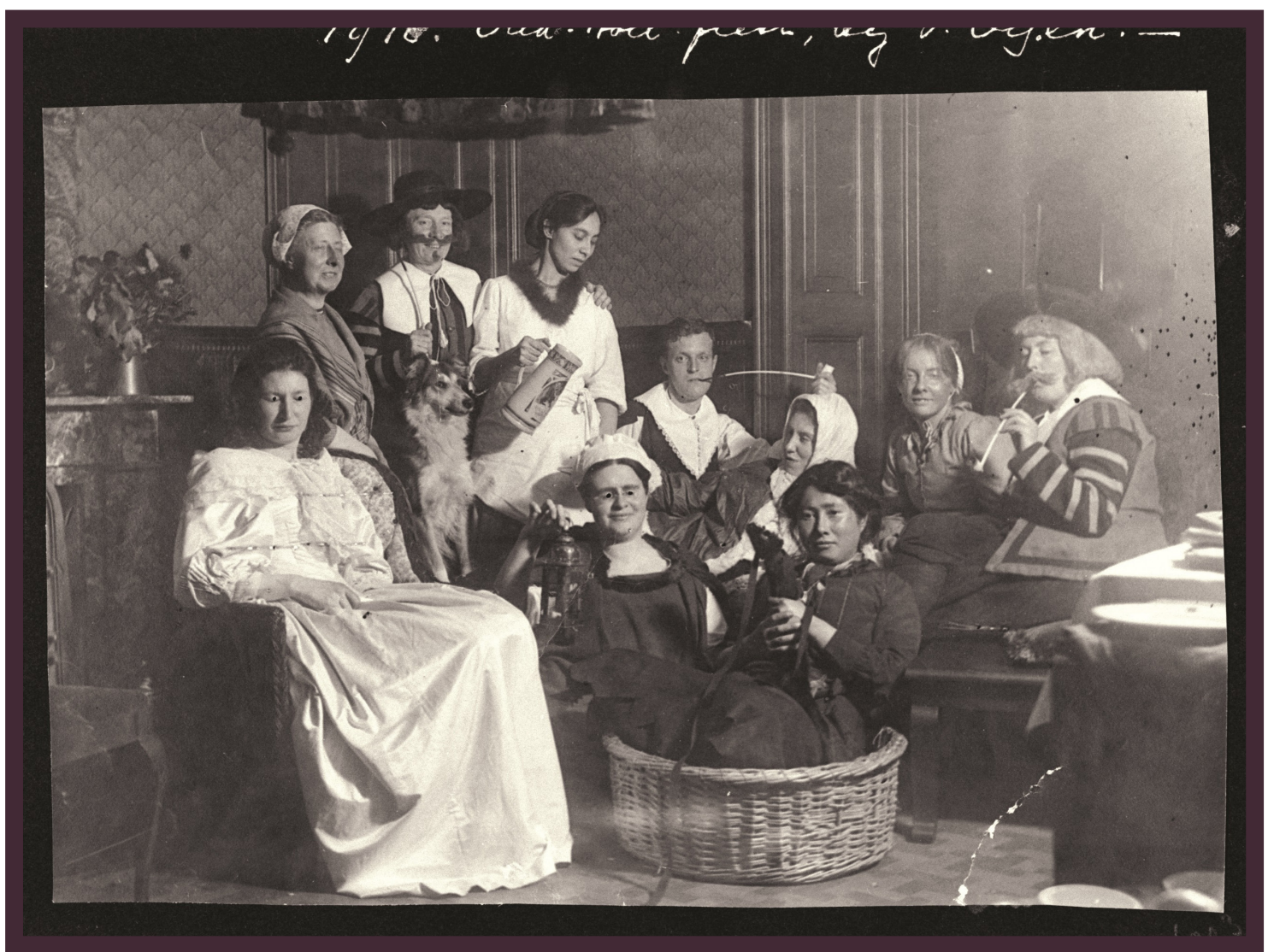

FIGURE 21 Johanna Westerdijk with her friends in costumes, 1918. Collection: Atria. The Institute on Gender Equality and Women's History in Amsterdam (100006003).

The term cross-dressing pertains to the wearing of typically gendered clothing of the opposite sex, assuming the binary of gender distinction (Sears, 2014, p. 3). One photograph shows Westerdijk wearing a hat, a black jacket, and a large black bow under her neck (Figure 22). This picture represents one of few of Westerdijk's portraits in which she acted as a man. She wore the outfit during the carnival, during her stay in Munich. This costume was worn to protect her from being unwillingly kissed by strangers, which was one of the customs she disliked about the carnival (Faasse, 2012, p. 68). Westerdijk dressed as a man to partake in a folk holiday that provided an opportunity to wear a costume and alter one's identity. Therefore, her cross-dressing practice can be interpreted as a manifestation of her sense of humour, or as a form of rebellion against the culturally imposed restrictions on women. Her portraits from her trip to the US in 1914, likewise, have a distinctly masculine character. In one photo, Westerdijk stands between a group of men and women, and appears to be one of the men at first glance, dressed in a jacket and a soft hat, with a ribbon tied under her neck, holding a walking stick. 


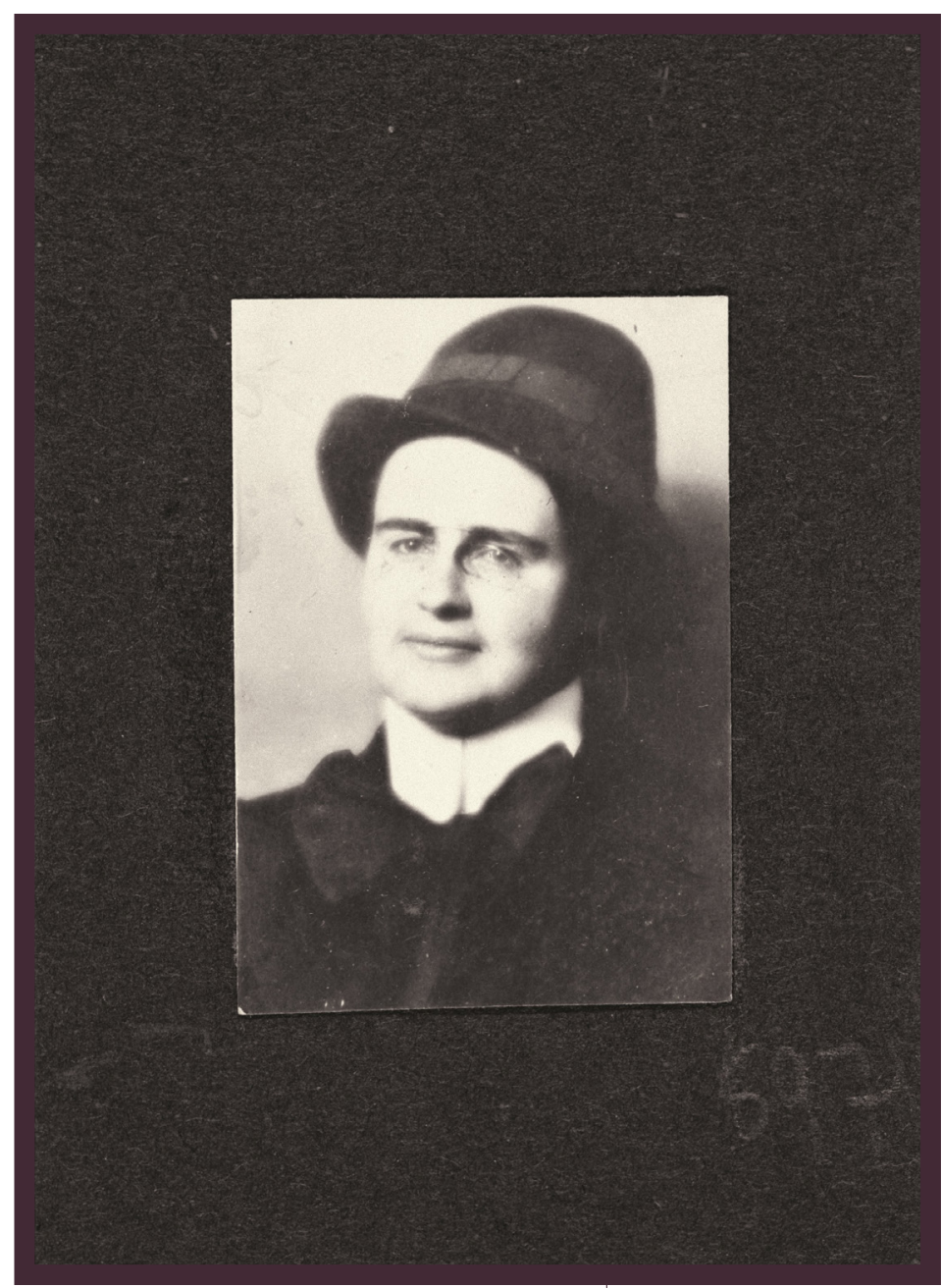

\section{Daily clothing is} meant to position the self in a social context, and it can display many different personalities.

Costumes are temporary, and they allow an individual to be another person, not in the sense of being someone else but rather another version of the self (Shukla, 2015, pp. 3-6). This interpretation is the most suitable for Westerdijk.

\section{QUEST FOR FREEDOM}

Westerdijk was more preoccupied with the social inequality between genders than political rights for women, yet she did express her disagreement with some of the social limitations that women faced (Bosch, 1994, pp. 405-412; Pegtel, 2018, p. 107). During her trip to the US, Westerdijk was outraged by the social restrictions placed on women; for example, she was prohibited from smoking with men in a public space (Segrave, 2005, p.

FIGURE 22 Johanna Westerdijk in a hat, 1906. Collecti on: Atria. The Institute on Gender Equality and Women's History in Amsterdam (100005971). 59-77). Before the 1920s, American women were usually not allowed to smoke in public; whenever an exception was made, it would arouse controversy. This prohibition applied especially to colleges, where female students could be expelled from university not only for smoking on campus but even in their 
dormitories (Segrave, 2005, pp. 61-62). To Westerdijk, who had experienced much freedom during her studies in Munich and Zurich, American constraints came as a shock (Bosch, 1994, p. 407; Zadoks \& Van Bruggen, 2008, p.161; Faasse, 2012, pp. 127-131). One photograph shows Westerdijk smoking a cigarette, while simultaneously presenting herself as an elegant young lady, attired in a blouse made of fine fabric with open embroidery and a patterned scarf tied around her neck in an effective bow, in line with the standards of her era (Figure 23). She keeps the cigarette poised in her raised hand, in front of her face as if showing off the fact that she was smoking. Her face expresses pride and seems to communicate that smoking is a manifestation of freedom and entitlement (Bosch, 1994, p. 331; Faasse, 2012, p. 157, Pegtel, 2018, p. 99). Interestingly, a cigarette appeared in fashion plates much later in the 1920s, when a cigarette holder became a popular accessory (Art deco fashion, 2007). This contrast between the cigarette and her feminine clothing does not reveal a desire to be a man, but a demand of freedom for women.
Westerdijk was a social person; she used to go out and spend time much of her time surrounded by her friends (Pegtel, 2018, p. 102). In one photograph taken in 1912 during a reunion of former biology students in café "Eik and Linde," she is dressed in a typical feminine outfit, yet her neck is adorned by a tie, giving her a slightly masculine look (Figure 24). Some other pictures also depict Westerdijk in similar apparel; for instance, two photos taken in 1906 in an atelier in München, which depict a theatrical, posed character. In both pictures, Westerdijk wearing a sophisticated female hat is seated at a small table with a man; the first photo shows the couple in a thoughtful pose, with their heads supported, while the second depicts them making a toast with two large beer mugs. These photos reflect Westerdijk's sense of humor and are probably the result of the enjoyment that transpired at the thresholds of this German photographic atelier. More importantly, the images reveal the significance of the act of breaking taboos for Westerdijk. Her search for freedom entailed engaging in enjoyable activities and treating her position with some levity. 


\section{Westerdijk's style should be interpreted in the context of the features of her character and approach to gender equality.}

In her daily life, she did not recognize the constant necessity of demonstrating equality with men; however, on some special occasions, she conveyed her disagreement with women's positions in society by wearing male clothing. The cross-dressing practice of Westerdijk can be compared to wearing a costume, which allows for the declaration of ideals and challenging of core values. For Westerdijk, dressing up as a man was a means of assuming a different identity and social position, and was interesting to her primarily because of the freedom this action would offer. Nevertheless, Westerdijk celebrated her femininity as well.

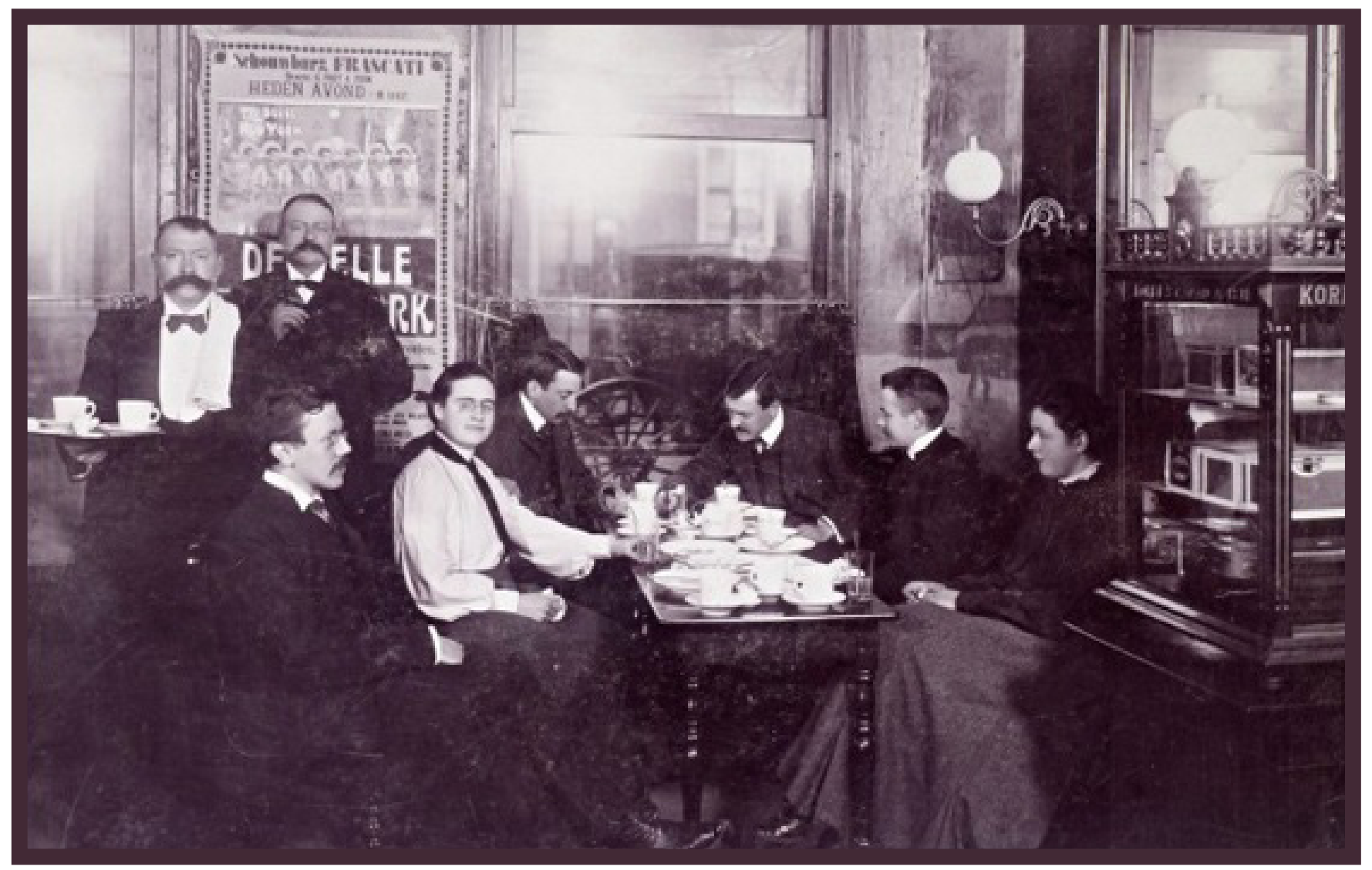




\section{CONCLUSION}

The analysis of visual sources allows several conclusions to be drawn regarding Westerdijk's clothing style and approach to personal appearance, fashion, and aesthetics. The Dutch scholar had her own style that was not, however, detached from the current fashion trends. She chose her outfits and accessories consciously, revealing an eye for details, with key characteristics of her style being simplicity and elegance. In certain circumstances, the most important aspect of her apparel was convenience and suitability to the activities to be performed. Westerdijk did not reach farbbeyond societal norms in making clothing choices for physical activities, yet she was unafraid of new developments and was willing to maximize cultural changes, specifically surrounding fashion, that granted women more freedom.

The nature of the clothing worn by individuals provide insights into their character, mentality, and perspectives. In the case of Westerdijk, her self-fashioning confirms that she did not view being a woman as an obstacle in the academic world, and did not strive to prove her equal position with men through clothing. However, she observed the rampant gender inequalities of the period and experienced some limitations herself, for which her masculine clothing identity was an expression of the need to be someone else and remove these social barriers, if only for one moment.

\section{Westerdijk's}

professional and private lives were intertwined, and this reality was also reflected in her

\section{clothing.}

In this case study of Westerdijk's sartorial sense, the photographs are a primary source, which can significantly contribute to biographical research, and their role goes far beyond being an attractive illustration. The biographical context facilitates the reading of the significance of someone's clothes, and likewise, the conclusions drawn from this analysis enrich biographical studies. 
Art Deco Fashion. (2007). Amsterdam: Pepin Press.

Bass-Krueger, M., Kurkdjian, S. (2019). French Fashion, Women E the First World War, New York: Bard Center.

Boonekamp, P. M., Pieterse, Corné M.J., Govers, F., \& Cornelissen, B. J.C. (2019). "Johanna Westerdijk (1881-1961) - the Impact of the Grand Lady of Phytopathology in the Netherlands from 1917 to 2017”. European Journal of Plant Pathology 154:1, pp. $11-16$.

Bosch, M. (1988). “Een vrouwenhegemonie in Baarn. Professor Johanna Westerdijk, directrice van het Laboratorium 'Willie Commelin Scholten”'. Ed. T van Loosbroek, Geleerde vrouwen. Nijmegen: SUN, pp. 170-190.

Bosch, M. (1994). Het geslacht van de wetenschap: Vrouwen en hoger onderwijs in nederland 1878-1948. Amsterdam: Sua.

Carli, L. L., Alawa, L., Lee, Y. A., Zhao, B., \& Kim, E. (2016). “Stereotypes About Gender and Science: Women $\neq$ Scientists”. Psychology of Women Quarterly, 40:2, pp. 244-260.

Coppens, M. (1996). Mode en belgique au XIXe siècle = mode en belgië in de $19 \mathrm{de}$ еeuw. Bruxelles: Weissenbruch.

Cunningham, P. A. (2003). Reforming Women's Fashion, 1850-1920: Politics, Health, and art. Kent-London: Kent State University Press.

Des, J. J. (2010). The Madame Curie Complex: The Hidden History of Women in Science. New York: Feminist Press.

Evans, G. (2013). Titanic Style: Dress and Fashion on the Voyage. New York: Skyhorse.

Faasse, P. (2012). Een beetje opstandigheid: Johanna Westerdijk: De eerste vrouwelijke hoogleraar van nederland. Amsterdam: Atlas Contact.

Faasse, P. (2019). “Genealogy of the Westerdijk Academic Family”. European Journal of Plant Pathology 154:1, pp. 5-10.

Fischer, G. V. (2001). Pantaloons E Power: A Nineteenth-Century Dress Reform in the United States. Kent: Kent State University Press.

Fukai, A. \& Suoh, T. (2012). Fashion: The Collection of the Kyoto Costume Institute: a Fashion History of the 20th century. London: Taschen.

Freidenreich, H. P. (2002). Female, Jerwish, and Educated. Bloomington: Indiana University. 
Kerling, L. C. P., Houten, J. G., \& Bruin-Brink, G. (1986). “Johanna Westerdijk: Pioneer Leader in Plant Pathology”. Annual Review of Phytopathology 24, pp. 33-41.

Klemensiewicz, Z. (1913). Zasady taternictwa. Lwów: Sekcya turystyczna Towarzystwa Tatrzańskiego.

Kloek, E. (2009). Vrouw des huizes. Een cultuurgeschiedenis van de Hollandse huisvrouw. Amsterdam: Balans.

LaFollette, M. C. (1988). "Eyes on the Stars: Images of Women Scientists in Popular Magazines. Science”, Technology and Human Values 13, pp. 262-275.

Pegtel, A. (2018). Buitengewone vrouwen. In de voetstappen van Aletta Jacobs, Amsterdam: Amsterdam University Press.

Schippers, B., \& Roosje, G. S. (1997). "Hundred Years of History and the Future of the Foundation 'Willie Commelin Scholten Phytopathological Laboratory". European Journal of Plant Pathology 103:7, pp. 667-671.

Sears, C. (2014). Arresting Dress. Cross-Dressing, Law, and Fascination in NineteenthCentury San Francisco. Durham: Duke University Press.

Segrave, K. (2005). Women and Smoking in America, 1880-1950. Jefferson: McFarland \& Co.

Shukla, P. (2015). Costume: Performing Identities Throught Dress. Bloomington: Indiana University Press.

Smith, C., Greig, C. (2003). Women in Pants Manly Maidens, Corvgirls, and Other Renegades. New York: Harry N. Abrams.

Steele, V. (2001). The Corset: A Cultural History. New Haven-London: Yale University Press.

Twigg, J. (2014). Fashion and Age: Dress, the Body and Later Life. London: Bloomsbury.

Van Godtsenhoven, K. (2012). Een sportief leven. Tenniskleding, broekrokken \& amazonekostuums". Living Fashion. Daily Women's Wear/Een leven in mode. Vrouwenkleding. 1750-1950. Tielt: Lannoo N.V.

Wilson, E., Taylor, L. (1991). Through the Looking Glass: A History of Dress from 1860 to the Present Day. New York: Parkwest, London BBC Books.

Zadoks, J. C., \& Van Bruggen, A. H. C. (2008). “Johanna Westerdijk (1883-1961). The Grand Lady of Dutch Plant Pathology”. Ed. J. B. Ristaino, Pioneering Women in Plant Pathology. St. Paul: APS Press, pp. 155-167. 


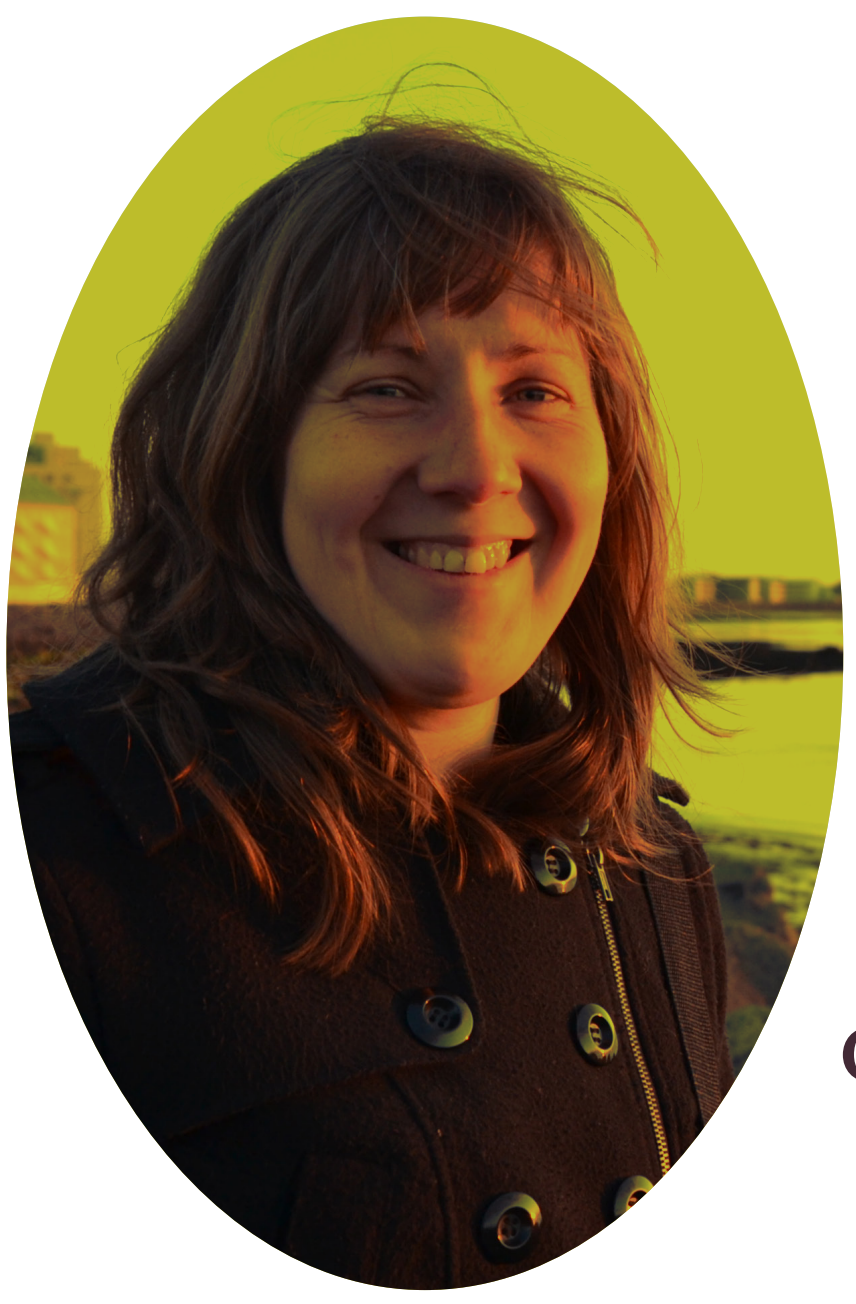

Marta Kargól, $\mathrm{PhD}$, received her MA in History (2007) and History of Art (2009) at Jagielloński University in Cracow.

In 2013, she obtained her PhD in Cultural Anthropology for the dissertation "Tradition in fashion: Dutch regional dress in various contexts of the contemporary culture" (written in Polish), published in 2015. She is also the author of two exhibition catalogues written in Dutch and English. Furthermore, she worked as assistant curator for the exhibition Women of Rotterdam (Museum of Rotterdam, 2017). Since 2016, she writes regularly about contemporary textile art for the Dutch periodical Textiel Plus. Her research interests include the history of female dress and fashion in the nineteenth and twentieth century, heritage of regional dress, economic and gender aspects of home-made clothing, and socially engaged fibre art.

\section{ARTICLE CITATION}

Kargól, Marta. "Fashioning the Academic and Private Self: The Clothing of Johanna Westerdijk in the Context of her Biography." Fashion Studies, vol. 3, no. 1, pp. 1-34, https://www.fashionstudies.ca/fashioning-the-academic-and-privateself, https://doi.org/10.38055/FS030109. 


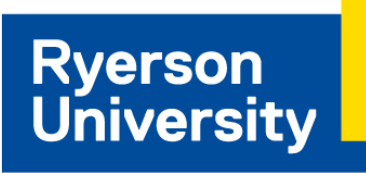

Fashion

Faculty of Communication

\& Design

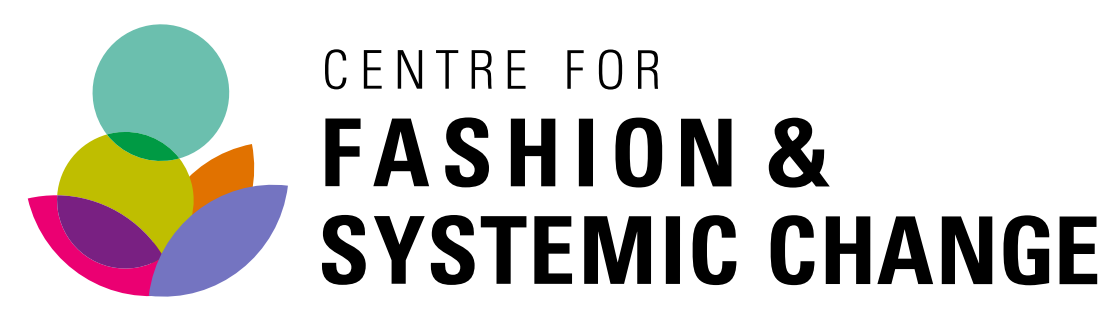

Froms SH/ON

\section{ISSN 2371-3453}

Copyright (@) 2020 Fashion Studies - All Rights Reserved

Creative Commons Attribution-NonCommercial-NoDerivatives 4.0 International (CC BYNC-ND 4.0) license (see: https://creativecommons.org/licenses/by-nc-nd/4.0/) 